
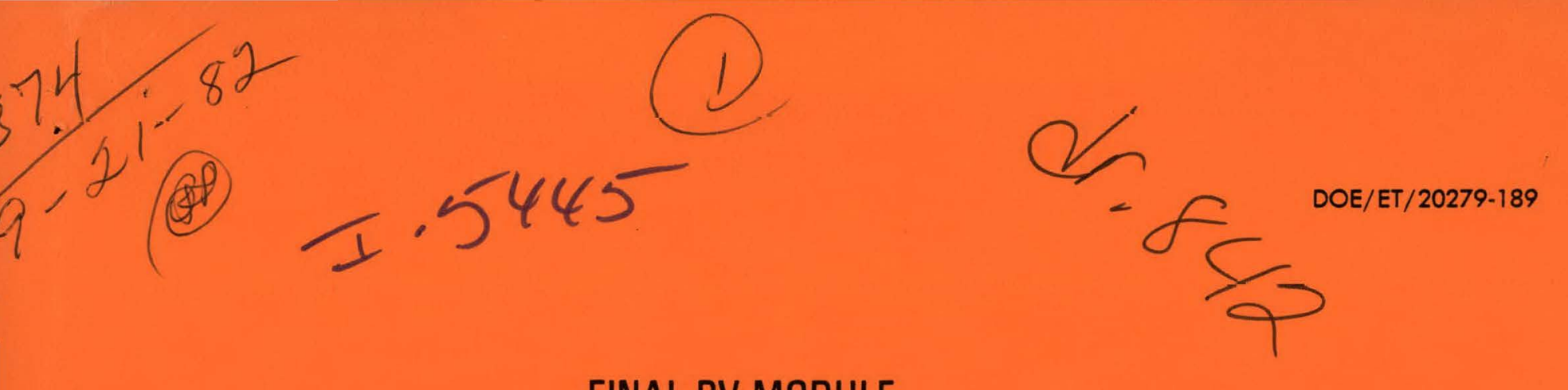

\title{
FINAL PV MODULE \\ DEGRADATION-ANALYSIS REPORT
}

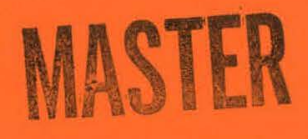

June 1982

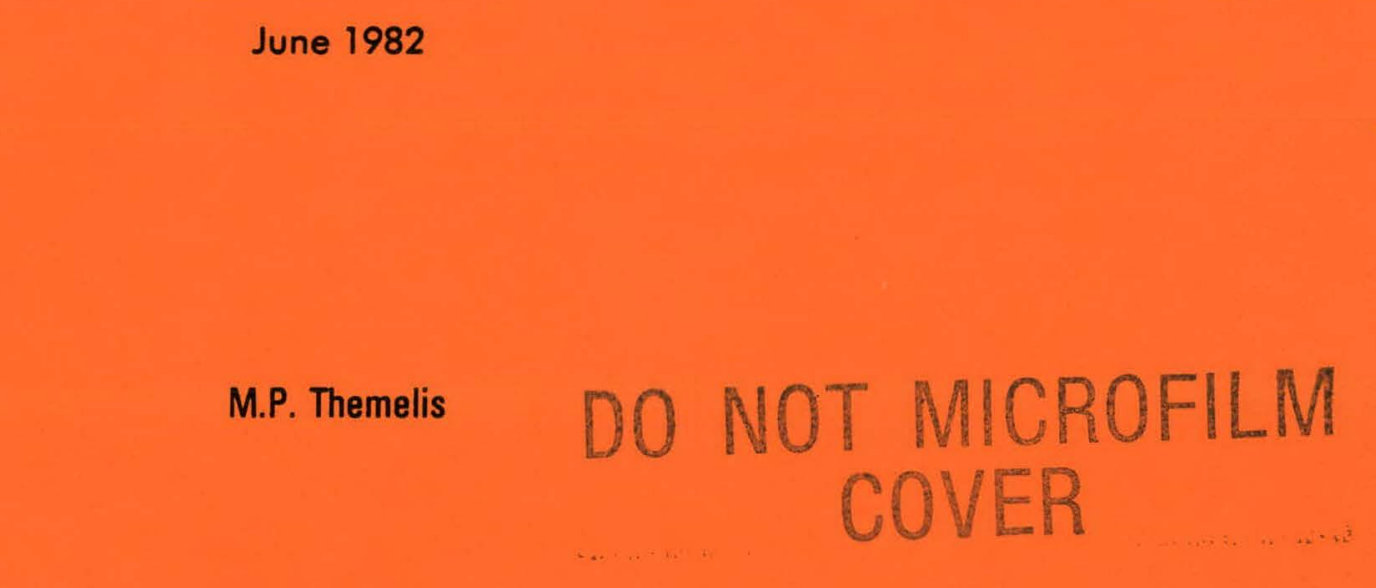

$$
\text { Prepared for }
$$

THE U.S. DEPARTMENT OF ENERGY

UNDER CONTRACT NO. DE-ACO2-76ET20279

(1)

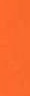

Prepared for 


\section{DISCLAIMER}

This report was prepared as an account of work sponsored by an agency of the United States Government. Neither the United States Government nor any agency Thereof, nor any of their employees, makes any warranty, express or implied, or assumes any legal liability or responsibility for the accuracy, completeness, or usefulness of any information, apparatus, product, or process disclosed, or represents that its use would not infringe privately owned rights. Reference herein to any specific commercial product, process, or service by trade name, trademark, manufacturer, or otherwise does not necessarily constitute or imply its endorsement, recommendation, or favoring by the United States Government or any agency thereof. The views and opinions of authors expressed herein do not necessarily state or reflect those of the United States Government or any agency thereof. 


\section{DISCLAIMER}

Portions of this document may be illegible in electronic image products. Images are produced from the best available original document. 
This book was prepared as an account of work sponsored by an agency of the United States Government. Neither the United States Government nor any agency thereof, nor any of their employees, makes any warranty, express or implied, or assumes any legal liability or responsibility for the accuracy, completeness, or usefulness of any information, apparatus, product, or process disclosed, or represents that its use would not infringe privately owned rights. Reference herein to any specific commercial product, process, or service by trade name, trademark, manufacturer, or otherwise, does not necessarily constitute or imply its endorsement, recommendation, or favoring by the United States Government or any agency thereof. The views and opinions of authors expressed herein do not necessarily state or reflect those of the United States Government or any agency thereof.

Additional copies available from the National Technical Information Service, U.S. Vepartment of Commerce, Springfield, Virginia 22161.

Price: Paper Copy $\$ 9.00$

Microfiche $\$ 4.00$ 
June 1982

FINAL PV MODULE DEGRADATION-ANALYSIS REPORT

\section{DEGRADATION-ANALYSIS REPORT}

June 1982

M.P. Themelis

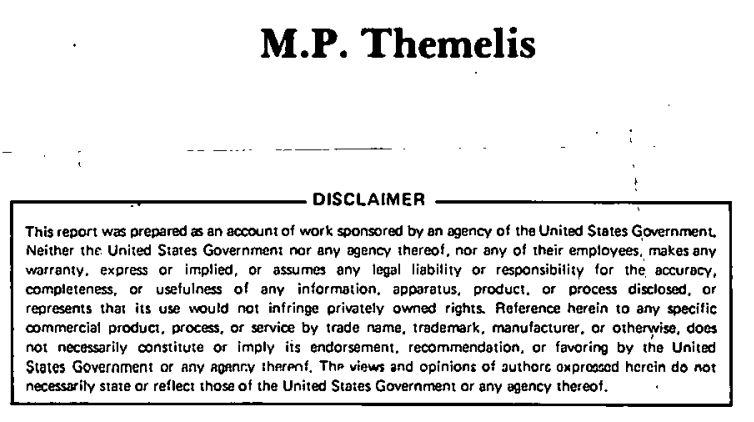

Massachusetts Institute of Technology Lincoln Laboratory

Lexington, Massachusetts 02173-0073

Prepared for

THE U.S. DEPARTMENT OF ENERGY

UNDER CONTRACT NO. DE-ACO2-76ET20279

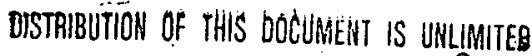




\section{THIS PAGE}

\section{WAS INTENTIONALLY \\ LEFT BLANK}


ABSTRACT

The U.S. Department of Energy has set a 20-year lifetime goal for terrestrial photovoltaic modules. In its capacity as a Residential Photovoltaic Field Test and Applications Center, Massachusetts Institute of Technology. Lincoln Laboratory has established various experimental test sites throughout the United States, containing $P V$ modules from several manufacturers, and serving as test beds for photovoltaic system components. This report summarizes the degradation analysis performed on modules removed from several test sites during 1981. 
THIS PAGE

\section{WAS INTENTIONALLY \\ LEFT BLANK}


TABLE OF CONTENTS

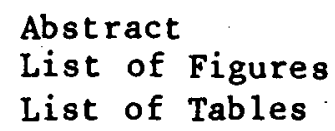

1. INTRODUCTION 1

2. NATURAL BRIDGES NATIONAL MONUMENT 5

2.1 Discoloration

2.2 Cracked Cells

2.3 Scratches

2.4 Electrical

2.5 Conclusions

\section{1}

3. MIT CAMBRIDGE $\quad 15$

3.1 Block I-Model A Modules 15

$\begin{array}{lll}3.2 & \text { Block II-Model C Modules } & 17\end{array}$

3.3 Block II-ModeI D Modules 20

3.4 Block II-Model B Modules 22

3.5 Block III-Model C Modules 25

$\begin{array}{lll}3.6 & \text { Block III-Model D Modules } & 28\end{array}$

3.7 Block III-Model F Modules 29

3.8 Block III-Model E Modules *. 36

3.9 Cleaning of Modules $\quad 36$

4: MEAD, NEBRASKA, AGRICULTURAL EXPERIMENT 45

4.1 Block II-Mode1 C Modules. 45

4.2 Block II-Model D Modules 52

4.3 Summary 53

$\begin{array}{ll}\text { References } & 57\end{array}$ 


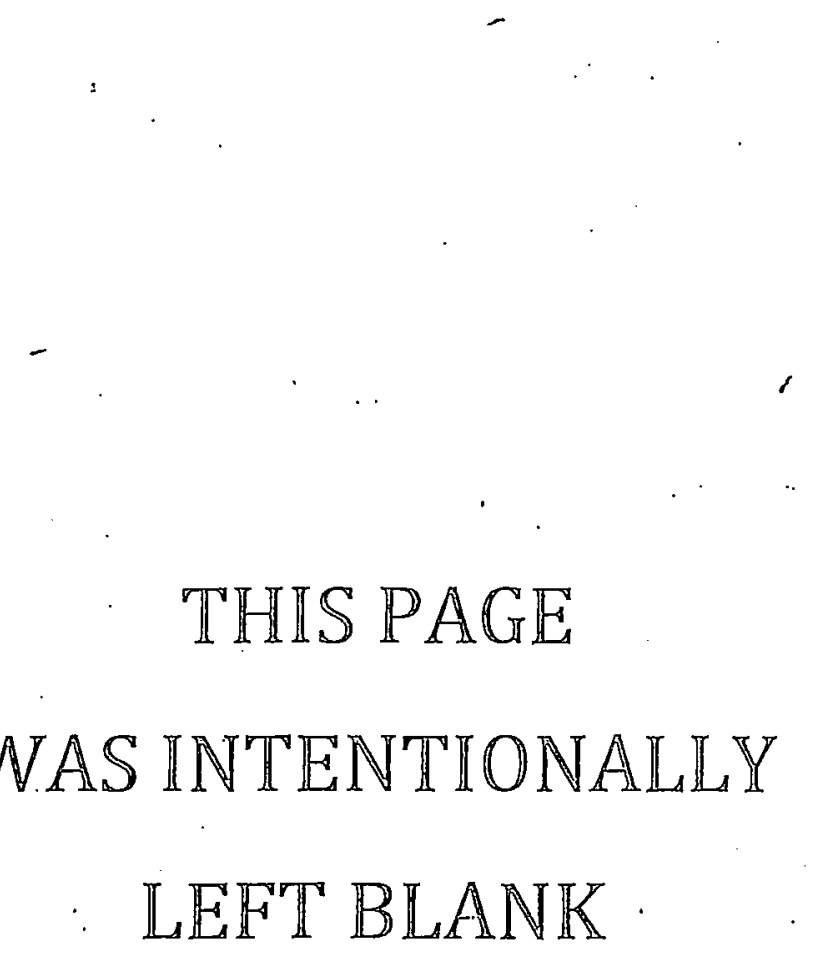


Figure No.

Title

Page

Partially Discolored Main Collector (Model E)

Partially Discolored Main Collector (Model E)

Multiple Lines of Discoloration/Main Collectors Discolored

Line of Discoloration/Yellowing of Tedlar (Model E)

Closeup, Edge Chip (Model E)

Miswired Block III Model C Cell

Discoloration of Silicone Gel and Specks of White Residue

Corrosion on Model F Terminals

Dirt on Seeping RTV Gel on Model F Module

LAPSS Curve Indicating Leakage Current through

Positive Terminal

I-V Curve When no Leakage Current Exists between

a Terminal and the Case

I-V Curve of the Same Module Indicating Leakage

Current through Positive Terminal

Model $C$, before and after cleaning (Block II)

Model $C$, before and after cleaning (Block III)

38

15

Model $D$, before and after cleaning (Block II)

39

Model $D$, before and after cleaning (Block III) 41

Model B, before and after cleaning (Block II) 42

Model F, before and after cleaning (Block III) 43

Models A (Block I), D (Block III), E (Block III),

and $F$ (Block III), before cleaning

I $-V$ Curve, Model A, be fore Cleaning 50

$I-V$ Curve, Model A, after Cleaning 
Table No.

Title

Page

1

2

3

4

5

6

7

Physical and Electrical Characterlstics of

Degradation Modules

LAPSS and Leakage Current Test Results for Model E Modules

Model C and D Block II Modules: Comparison Forward and Reverse Dark Curves and High Voltage Leakage Comparative Table of Peak Powers before and after Cleaning for MIT-Cambridge Modules

Block II Model C Modules, Comparative Table of LAPSS

Results, before and after Cleaning

Block II Model C Modules, Comparative Table of

Forward and Reverse Dark Curves and High Voltage

Leakage Currents

Block II Mulel D Moduloo, Comparative Tuble of LAPSS

Results, before and after cleaning 


\section{INTRODUCTION}

Massachusetts Institute of Technology Lincoln Laboratory. (MIT LL) has served as a Field Tests and Applications Center for the U.S. Department of Energy (DOE) in order to evaluate the energy potential of photovoltaic (PV) components in various test applications. As part of the DOE Jet Propulsion Laboratory's (JPL) Large-Scale Procurement Program, MIT LL received PV modules containing silicon cells from various manufacturers for use at its experimental test sites. (The names of the module manufacturers are not relevant to this report; the module types will be referred to as Module A, $B, C, D, E$, and F.) Each module was inspected visually at the factory by JPL, and a "road map" outlining its physical appearance and workmanshiprelated anomolies was completed to establish the initial conditions present in the module. Subsequent degradation is measured against these conditions.

From November 1981 through January 1982, visual and electrical degradation analyses were performed on 47 modules from the following sites: Natural Bridges National Monument (NBNM) in Utah; Massachusetts Institute of Technology (MIT) in Cambridge, Massachusetts; and the University of Nebraska at Mead, Nebraska. The types of modules that were evaluated were:

- Block I: Model A;

- Block II: Models B, C, and D; and

- Block III: Models C, D, E, and F.

Table 1 lists the electrical and physical characteristics of each type of module.

Five Model E Block III modules were removed from the NBNM site on 21 October 1981 and returned to the Materials, Processes and Testing (MP\&T) l.aboratory for degradation analysis. It has been previously implied (in a private communication with the JPL Failure Analysis Group in 1981) that lines 
TABLE 1

PHYSISAL ARD ELECTRICAL CHARACTERISTICS OR DEGRADATION MODULES

\begin{tabular}{|c|c|c|c|c|c|}
\hline Module Type & 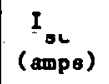 & $\begin{array}{c}v_{00} \\
(\operatorname{voltc})\end{array}$ & $\begin{array}{l}\text { Poak Poyer } \\
\text { (watts) }\end{array}$ & $\begin{array}{l}\text { Dimenglons } \\
\text { (mom) }\end{array}$ & $\begin{array}{l}\text { Phymical } \\
\text { Pédeuroo }\end{array}$ \\
\hline $\begin{array}{l}\text { Block I } \\
\text { Model A }\end{array}$ & 0.66 & 11.6 & 5.45 & $633 \times 124 \times 69$ & $\begin{array}{l}\text { A1- "I-Beam" extrueion subatrace } \\
2.3 \text {-mm glase over oilicone encapeulant } \\
20 \text { ceils, 50-am diameter }\end{array}$ \\
\hline $\begin{array}{l}\text { Block II } \\
\text { Model C }\end{array}$ & $0: 58$ & 24.3 & 10.2 & $589 \times 290 \times 25$ & $\begin{array}{l}\text { Stamped A1 substrace } 3.2 \text { mo oilicone } \\
\text { encapoulant } 44 \text { cello, } 56 \text { diemeter }\end{array}$ \\
\hline Model B & 1.96 & 23.3 & 33.9 & $1168 \times 389 \times 48$ & 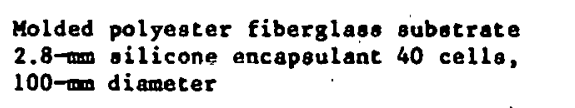 \\
\hline Model D & 1.40 & 23.7 & 22.0 & $582 \times 982 \times 59$ & 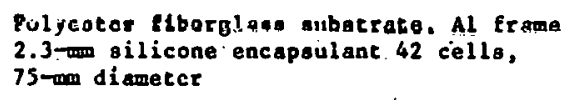 \\
\hline $\begin{array}{l}\text { Block III } \\
\text { Model } 8\end{array}$ & 1.40 & 23.2 & 22.2 & $1160 \times 232 \times 36$ & 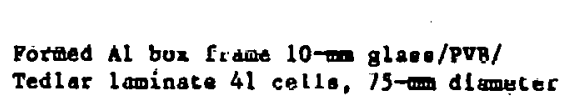 \\
\hline Model $\mathrm{P}$ & 4.90 & 7.2 & 26.5 & $580 \times 580 \times 50$ & $\begin{array}{l}\text { Pormed acainleas oteel pan, } 4.3-\text { an glass } \\
\text { front, silicone gel encapoulant } 48 \text { cells, } \\
75 \text { - diameter }\end{array}$ \\
\hline Model c & 0.58 & 24.1 & 10.7 & $582 \times 287 \times 48$ & $\begin{array}{l}\text { Pinned Al extrusion substrate, } \\
5-\operatorname{mil} \text { ilicone encapsulant } 44 \text { doild, } \\
56-\operatorname{diameter}\end{array}$ \\
\hline Model o & 1.40 & 23.7 & 21.8 & $582 \times 582 \times 33$ & $\begin{array}{l}\text { Polyester fiberglass substrate, Al frame } \\
2.3-\operatorname{mos} \text { ilicone encapoulant } 42 \text { cells, } \\
75-\operatorname{mom} \text { diameter }\end{array}$ \\
\hline
\end{tabular}

NMTP: Descriptions are based on $100 \mathrm{mH} / \mathrm{cm}^{2}$ and $28^{\circ} \mathrm{C}$; average values of modules at southern California aiteo. 
of discoloration on the cells of these modules had been found to coincide with crack paths in cells. To better study this condition, modules, both with and without this condition, were removed from the site.

Eighteen modules were removed from the Environmental Test site at MIT in Cambridge in October 1981. Eight of these modules had been exposed for approximately 47 months and, during that time, had twice been returned to the MP\&T Laboratory for testing and cleaning. The remaining ten modules had been continuously exposed for 34 months. Periodic electrical tests were performed in situ on these modules.

Twenty-four modules were removed from the University of Nebraska Agricultural Test Site at Mead, Nebraska, in September 1981. These modules had been part of a degradation study since their initial installation in July 1977; they have been returned to the MP\&T Laboratory for analysis at least twice in the past 50 months.

With the Nebraska and MIT-Cambridge modules, an attempt has been made to determine the physical changes which have occurred since the previous analyses, by carefully comparing all sets of data.

As this is the first time that degradation analysis has been performed on the Model $E$ modules from NBNM, any conditions found will be compared with the receiving inspection road maps made by JPL inspection personnel at the factory. 
THIS PAGE

\section{WAS INTENTIONALLY}

: LEFT BLANK 


\section{NATURAL BRIDGES NATIONAL MONUMENT}

During December 1981, electrical and visual degradation analyses were performed on five Model E Block III modules that had been removed from NBNM on 21 October 1981, after 21 months of field service. New or worsening conditions found in these modules are summarized below and compared with receiving inspection data.

\subsection{Discoloration}

A discoloration of the grid lines was found near the edges of all of the 205 cells on the five modules. On four of the modules, the main collectors of six cells were either partially or completely discolored. This discoloration ranged from shades of deep rust to nearly black. Examples of this discoloration can be seen in Figures 1, 2, and 3 .

A slight yellowing of the Tedlar back surface was noted in the area between the cells and the aluminum frame. This condition was found along both sides of all five modules. This pattern of discoloration can be seen along the right side of Figure 4. The edge discoloration area has been enhanced by a black line at its boundary.

Discoloration of the anti-reflective (AR) coating was found along what appeared to be scratches on the surfaces of a couple of cells and also along the cracked areas of two cells.

\subsection{Cracked Cells}

Two of the five modules were found to contain one cracked cell each. On the first module, a cell was found which had an edge-to-edge crack running diagonally across the cell and cutting through both of the main collectors. A line of discoloration followed the crack across the cell, making the crack appear as a faint dark line within the discolored area. Figure 4 shows the line of discoloration and portions of the crack. The arrows indicate where the crack exits on both sides of the cell. 


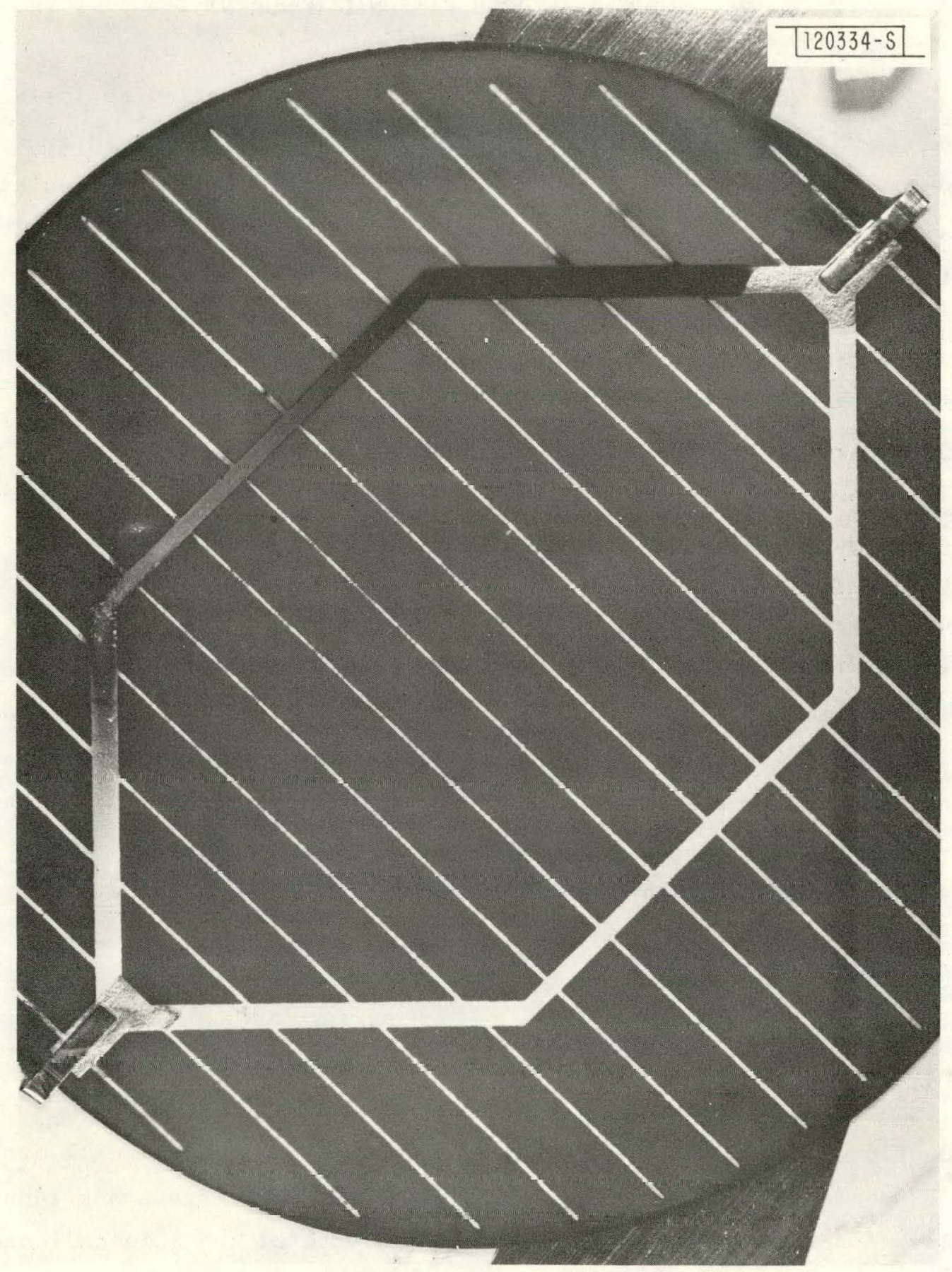

Figure 1. Partially Discolored Main Collector (Model E). 


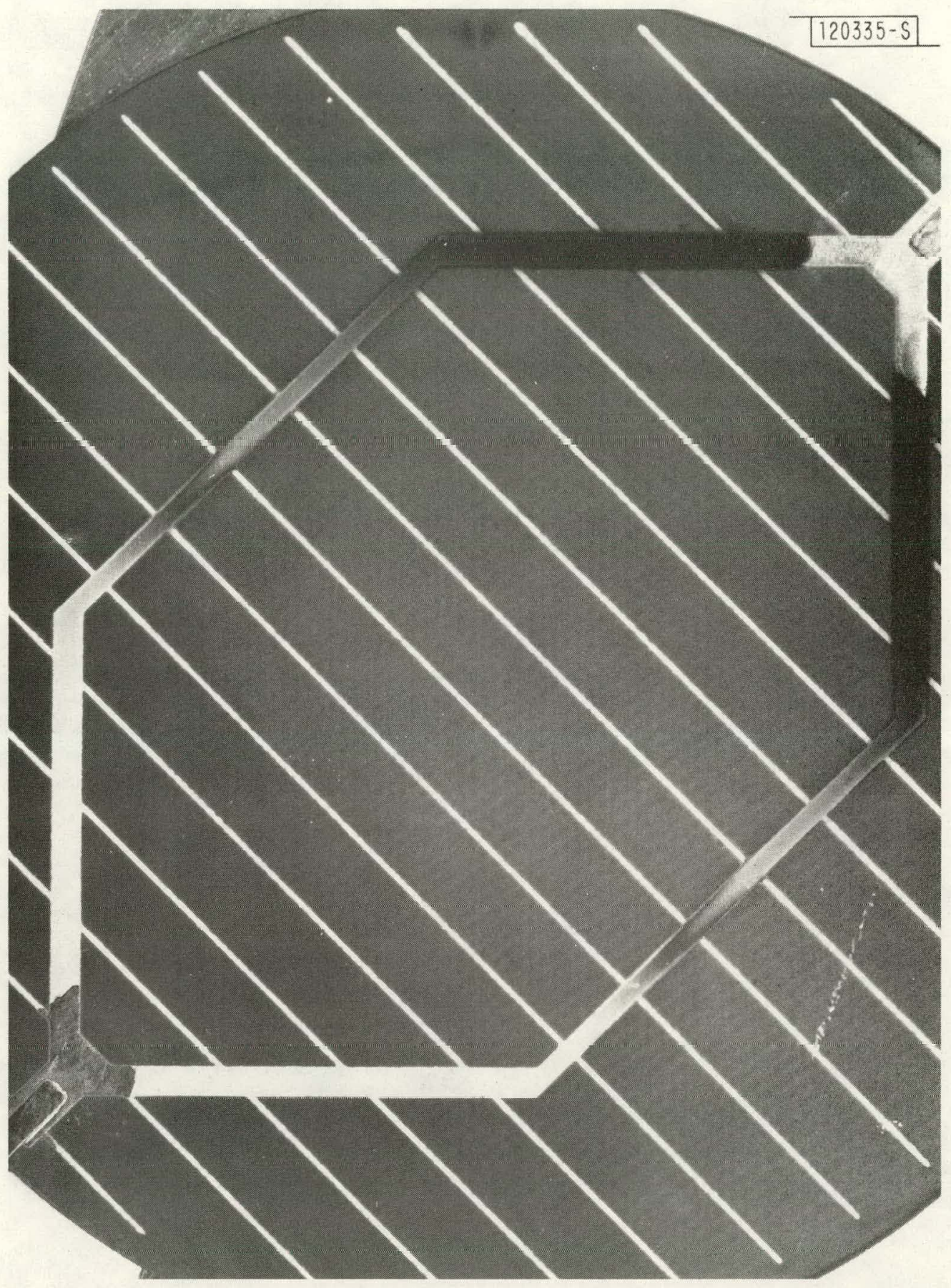

Figure 2. Partially Discolored Main Collector (Model E). 


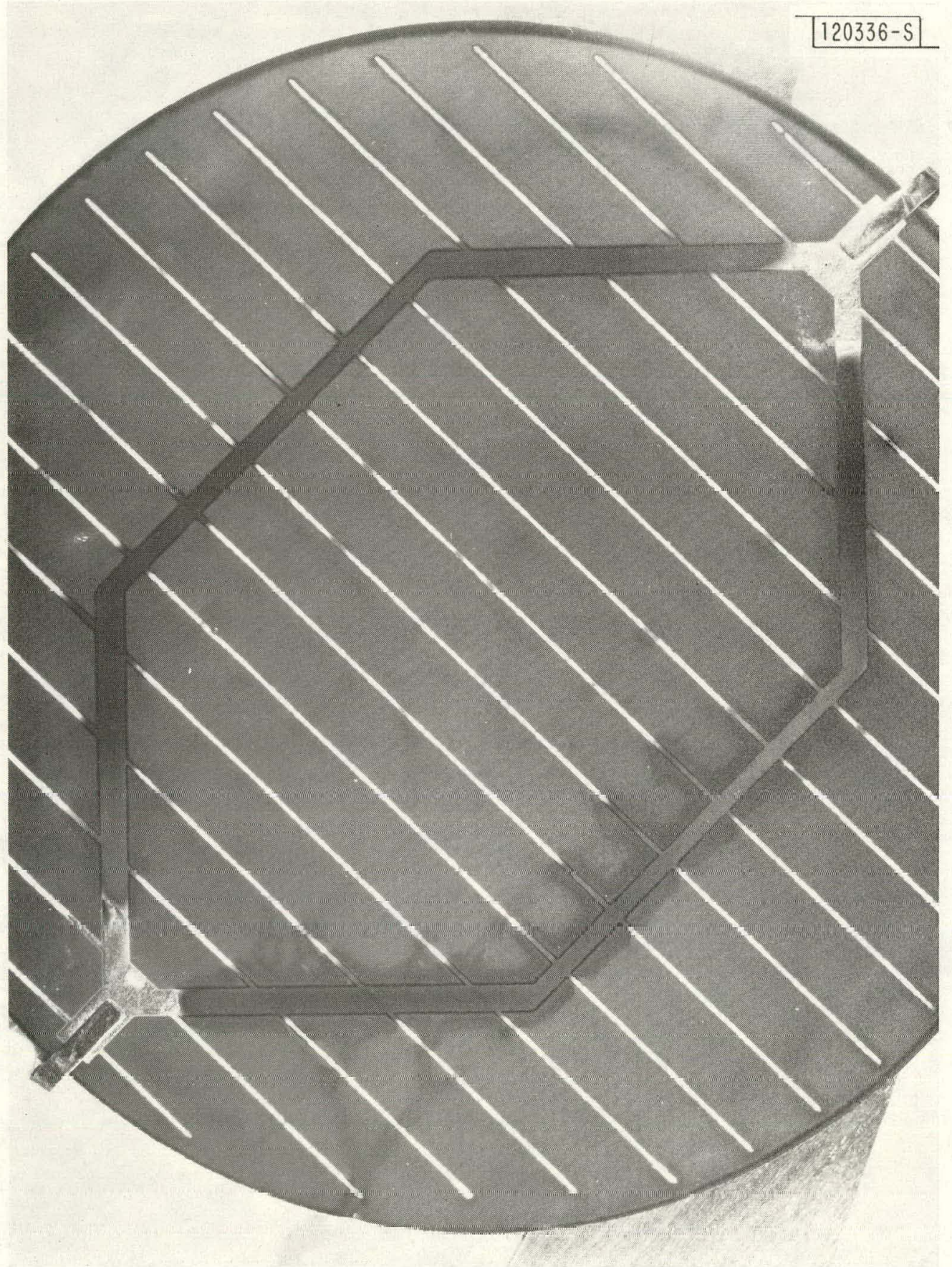

Figure 3. Mulliple Lines of Discoloration/Main Collcctors Discolored. 


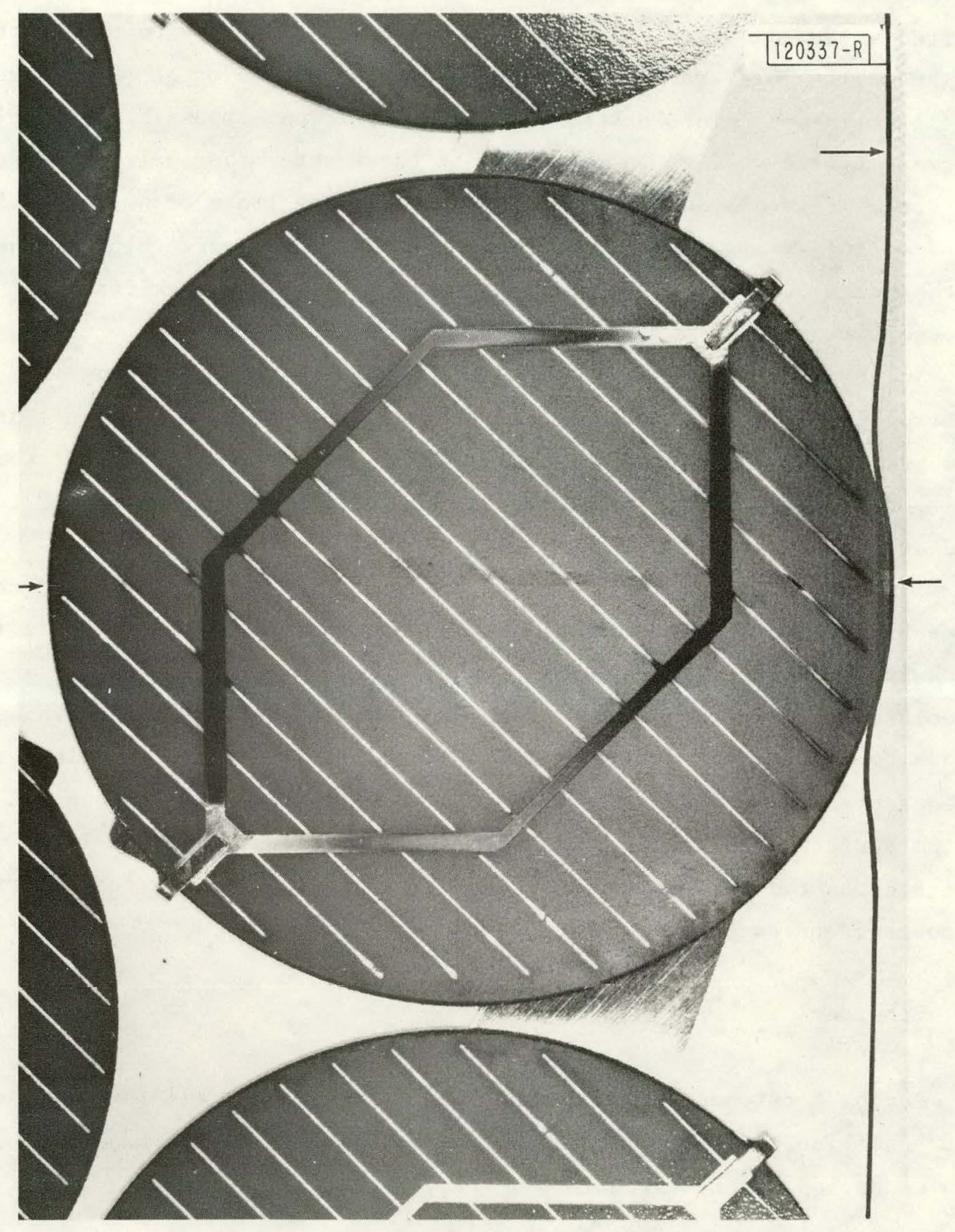

Figure 4. Lines of Discoloration/Yellowing of Tedler (Model E). 
On the remaining module, one cell was found to have a crack which had started at an edge chip and then appeared to progress toward the opposite end of the cell. This crack could be seen plainly at its origin, but, due to the multiple lines of discoloration on the cell, it was impossible to follow its progress up the cell or to determine if there were other hairline cracks in the area. Figure 3 shows the pattern of the many lines of discoloration found on this cell. Figure 5 shows a closeup of the edge chip and the origin of the crack (see arrow). The direction in which the crack traveled, as seen through a microscope at $35 \mathrm{X}$, has been enhanced.

In spite of the cracked cells, these modules were operating electrically, at elevated temperatures, when array curves were made in October 1981. Because they have also passed all of the electrical Lests during degradation analysis, these modules will be returned to NBNM to be used as future replacement spares, if needed.

The phenomena of these lines of discoloration along a crack do not necessarily confirm that this discoloration appears only where there is a crack in the cell. As can be seen in Figure 3, several lines of discoloration were running across the surface of the cell, yet no other cracks could be found at magnifications up to $35 \mathrm{X}$. It is possible that these lines appear wherever the AR coating on a cell has been disturbed. A scratch on the surface of the cell, a slight residue of flux, or any solvent remaining on the cell after the cleaning process could have reacted with the $\mathrm{AR}$ coating and caused the stains.

\subsection{Scratches}

Random scratches were found on the cover glass of all five modules. This condition was probably caused during the shipping and handling of the modules during installation in the array field.

\subsection{Electrica1}

The modules were flashed in the Large Area Pulsed Solar Simulator (LAPSS), and a normal I-V curve was obtained for each of the five modules. 


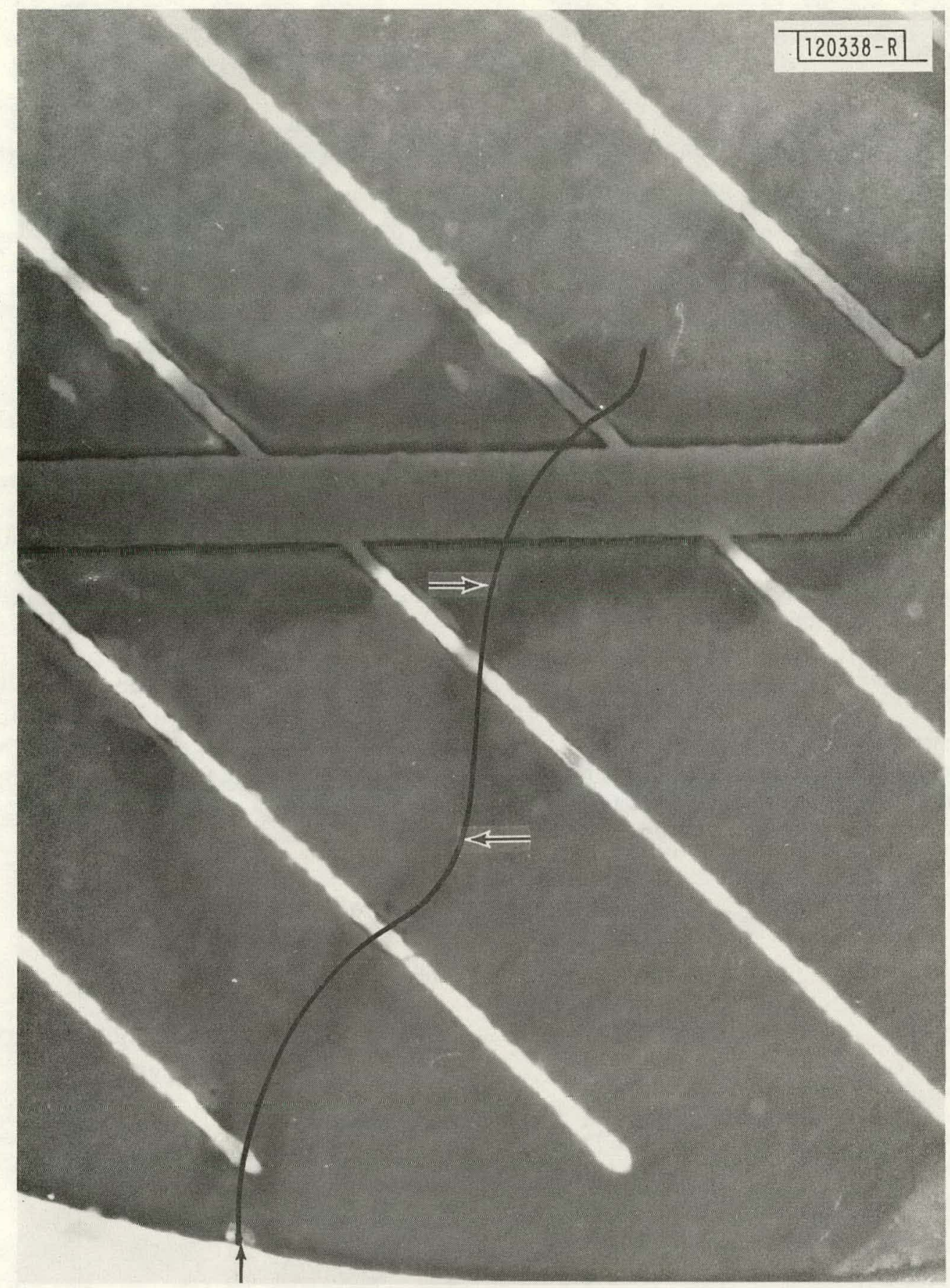

Figure 5. Closeup, Edge Chip (Model E). 
The open-circuit voltages ranged between 23.7 and 24.4 volts (V) while the short-circuit current for each module was on the order of 1.4 amperes (amp).

A high-voltage breakdown test was performed (1500 V for one minute) on each module, and leakage currents, ranging from 0.30 to 0.55 microamps ( $\mu a$ ) were found on the five modules.

Table 2 lists the results of the LAPSS and leakage current tests.

NOTE

In addition to the usual inspection method, these modules were also examined with the infrared (IR) inspection device. However, no cracks in the cells were found while using this method. There are two possibilities why the cracks were not detected by the IR device: the hairline cracks may not have been deep enough to cause the 1 ight to reflect back to the IR device or the external lights on the IR device were not at a proper angle to the cracks to cause a reflection.

Based on past experience with similar cells, the discoloration of the AR coating has made the smaller cracks more difficult and, at times, impossible to detect. Even with the advantages of using a bench microscope at a higher magnification and fiber-optic lights that can be used at unlimited angles, previously noted cracks could not always be detected again on subsequent inspections.

TABLE 2

LATSS AND LEAKAGE CURRENT TFIST RF.SULTS FOR MODEL E MODULES

\begin{tabular}{|c|c|c|c|c|}
\hline LL-S/N & $\begin{array}{c}I_{s c} \\
\text { amps) }\end{array}$ & $\begin{array}{c}\mathrm{V}_{\mathrm{m}} \\
\text { (vol€s) }\end{array}$ & $\begin{array}{c}\mathrm{P}_{\text {mux }} \\
\text { (watts) }\end{array}$ & $\begin{array}{c}\text { Leakage } \\
\text { Current } \\
\text { (microamps) }\end{array}$ \\
\hline 14415 & 1.42 & 23.94 & 23.84 & 0.49 \\
14416 & 1.42 & 23.83 & 23.03 & 0.55 \\
14417 & 1.42 & 23.78 & 23.84 & 0.37 \\
14418 & 1.42 & 23.93 & 24.02 & 0.55 \\
14419 & 1.40 & 24.36 & 21.55 & 0.30 \\
\hline
\end{tabular}




\subsection{Conclusions}

The conditions found in these modules, after 21 months of field service, were noted and then carefully compared with the initial receiving inspection road maps prepared by the JPL inspectors.

At the JPL receiving inspection, the following conditions were noted on all five of the modules: stains on cells, chips on the edges of the cells, and solder debris. A residue of flux was found on the cells of three modules, and one module was noted to contain cells on which there was some discoloration of the grid lines.

Two modules were found to contain one cracked cell each. The cracked cells were replaced, and the modules were reinspected, prior to acceptance, by the JPL inspectors. Neither one of the cracked cells, found during degradation analysis, was a replacement cell. However, one of the cracked cells was found, in another location, on one of the repaired modules. The cause of the cracked cells found during degradation analysis is unknown. However, as these modules appear to be working electrically, they will be used as future spares at NBNM.

In addition to the cracked cells, discoloration of the grid lines and main collectors appears to have increased with exposure time. Yellowing of the area between the cells and the side edges of the module frame has also increased with exposure time. However, none of these conditions appear to be affecting the electrical performance of these module at the present time. 
THIS PAGE

\section{WAS INTENTIONALLY}

$\therefore$ LEFT BLANK 


\section{MIT CAMBRIDGE}

In August 1977, two Block I and six Block II modules were installed on the rooftop of a six-story building at MIT in Cambridge, Massachusetts, as part of a soil-accumulation study. The modules consisted of two Block I Model A, two Block. II Model C, two Block II Model D, and two Block II Model B. In December 1978, the study was expanded to include ten Block III modules: four Model $C$, two Model D, two Model E, and two Model F. The physical and electrical characteristics of the Block I, II, and III modules can be found in Table 1 .

\subsection{Block I-Model A Modules}

\subsubsection{First Analysis: 5 Months Exposure}

\section{Visual}

Delamination was found along the edge seals and around the positive and negative terminal discs on both modules. A slight discoloration was noted around the terminal disc of one module.

\section{Electrical}

Symptoms of high voltage breakdown were found on both modules at the 500 and $1000 \mathrm{~V}$ settings. No significant changes were found on the measurement of the forward dark curve.

\subsubsection{Second Analysis: 11 Months Exposure}

\section{Visual}

Visual examination revealed discoloration of the main collectors on several cells of both modules and staining along the grid lines of most of the cells of both modules. Missing encapsulant along the terminal end-edge seal left a terminal disc partially exposed on one module, and a small chip was found in the protective glass cover of one module. 
Electrical

No changes were found since the first analysis.

\subsubsection{Final Analysis: 48 Months Exposure}

Visual

An increase in the number of cells with yellowed grids and main collectors was found on both modules. 'Original edge stains have turned brown on several cells of both modules. The top side portion of the plastic feedthrough insulator disc around the positive terminal has become cracked on both modules.

\section{Electrical \\ No changes were found since the first analysis.}

\subsubsection{Conclusions}

The discoloration of the main collectors and grid lines, the staining of the cells along the grid lines, and the darkening of the stains found on the edges of the cells do not appear to have any effect on the electrical output of these modulee.

The delamination along the edge seals does not appear to have allowed any appreciable amount of moisture to penetrate into the cell area.

The cracking of the plastic insulator discs on the top sides of the terminals may have been a result of thermal cycling as these discs appear to be bonded directly to the aluminum substrate. However, this condition does not appear to affect the electrical performance of these modules.

The partially exposed terminal disc presents a path for moisture to penetrate directly into the module. If a significant amount of moisture was to seep into the area adjacent to the terminal, a direct path for a short to the substrate could occur. However, this condition can be corrected by reflowing RTV along the edge seal in this area. 
The short circuits to the substrate, found on both of these modules during the high-voltage breakdown tests, were in all probability caused by the sharp downward hooks on the web-like interconnects that were noted on the receiving inspection road maps. It appears that the tip of one or more of the hooks had penetrated the insulation blanket as a result of thermal cycling. As this condition constitutes an electrical hazard, these modules are considered failures.

\subsection{Block II-Model C Modules}

\subsubsection{First Analysis: 5 Months Exposure}

Visual

A light yellow discoloration in the area of the terminals was found on both modules, and delamination was found in a reworked area and around a mounting hole on one module.

\section{Electrical}

Forward and reverse dark curves measurements showed no significant changes. The high-voltage breakdown test showed the leakage current at $1000 \mathrm{~V}$ to have decreased to one-half the original value for both modules.

\subsubsection{Second Analysis: 11 Months Exposure}

\section{Visual}

Discoloration around the terminals has become a darker shade of yellow. Delamination, caused by the rotation of the mounting boss during assembly onto the subframes, was present around the mounting holes on both modules; a spot of delamination 1/32-inch wide was found on one cell.

The metal around the base of a terminal post was found to be tarnished on one module. Staining along the grid lines was found on most of the cells of both modules. This condition is believed to be caused by the migration of tin, from the solder which covers the grid lines, into the AR coating on the cell. 


\section{Electrical}

No significant changes were found on the forward and reverse dark curve measurements. During the high-voltage breakdown tests at $1000 \mathrm{~V}$, the leakage currents, which had decreased to one-half of their original values after five months, had increased slightly from these values.

\subsubsection{Final Analysis: 48 Months Exposure}

\section{Visual}

The AR coating on the majority of the cells on both modules had faded to or changed to a rusty hue. The dark stains on the cells, noted at receiving inspection, have also changed to a rust color. This condition is believed to be the result of the continuing migration of the tin from the solder on the grid linco into the AR coating.

The use of tools on the interconnects during fabrication has removed segments of the plating, exposing the copper beneath. These exposed areas tend to tarnish with exposure time. These tarnished areas were found on the majority of the interconnects on both modules. The mounting hardware and grounding screws on the rear side of both modules were badly rusted.

\section{Electrical}

A high-voltage breakdown test was performed at 1000 VDC on both modules. The leakage currents were noted to have increased 0.15 and $0.1 \mu \mathrm{a}$, respectively, after an additional 37 months in the field. A comparison of the receiving inspection, first, second; and final analysis leakage current results can be found in Table 3 .

Forward and reverse dark curves measurements were taken on both modules. On the forward dark curve, a decrease of $0.5 \mathrm{~V}$, was found on the first module. and an increase of $0.2 \mathrm{~V}$ was found on the other module. On the reverse dark curve, the first module showed a decrease of $2.0 \mathrm{milliamperes}(\mathrm{ma})$, and the other module showed a decrease of $1.0 \mathrm{ma}$ since the previous analysis. A comparison of the forward and reverse dark curve measurements can be found in Table 3 . 
TABLE 3

MODEL C AND D BLOCK II MODULES: COMPARISON FORWARD AND REVERSE DARK CURVES AND HIGH-VOLTAGE LEAKAGE

\begin{tabular}{|c|c|c|c|c|}
\hline LL-S/N & $\begin{array}{c}\text { Module } \\
\text { Type }\end{array}$ & $\begin{array}{c}\text { Forward } \\
\text { Dark } \\
\text { (V) }\end{array}$ & $\begin{array}{c}\text { Reverse } \\
\text { Dark } \\
\text { (ma) }\end{array}$ & $\begin{array}{c}\text { Leakage } \\
\text { Current } \\
(\mu a)\end{array}$ \\
\hline 3974 & Model C & 25.8 & 17.0 & 0.98 \\
5 mos. & Model C & 26.5 & 17.0 & 0.51 \\
11 mos. & Model C & 26.5 & 17.0 & 0.65 \\
48 mos. & Model C & 26.0 & 15.0 & 0.79 \\
4034 & Model C & 25.4 & 31.5 & 1.00 \\
5 mos. & Model C & 26.0 & 32.0 & 0.50 \\
11 mos. & Model C & 25.8 & 31.0 & 0.64 \\
48 mos. & Model C & 26.0 & 30.0. & 0.74 \\
4124 & Model D & 23.0 & 200.0 & 0.0 \\
5 mos. & Model D & 23.5 & 190.0 & 0.01 \\
11 mos. & Model D & 23.5 & 190.0 & 0.07 \\
48 mos. & Model D & 23.5 & 190.0 & 0.01 \\
4141 & Model D & 23.0 & 100.0 & 0.0 \\
5 mos. & Model D & 23.5 & 110.0 & 0.01 \\
1. mos. & Model D & 23.8 & 110.0 & 0.02 \\
48 mos. & Model D & 23.5 & 110.0 & 0.02 \\
\hline
\end{tabular}

\section{2 .4 Conclusions}

The discoloration of the RTV in the terminal areas affects the module only cosmetically. The discoloration of the AR coating does not appear to have caused any deficiencies during the electrical tests. There is no conclusive evidence that this condition has any effect on the output of these modules when they are installed in a working array.

There was no delamination found along the edge seals of these modules after 48 months of exposure. The internal delamination, found in a rework area of one module, does not appear to have grown. 
The rotation of the boss at the mounting holes during assembly was a design problem, and the subsequent generation of these modules has been designed to eliminate this problem. However, moisture has not penetrated the active area of these modules yet, so the delamination around the mounting hole has caused no electrical probiems.

The decrease in the leakage current between the receiving inspection and the first analysis was probably brought about by the gradual curing of the RTV encapsulant. As RTV will absorb some moisture when exposed to the environment (rain and/or humidity) and then dry out again when weather conditions change, the later increases in the leakage currents were probably due to the moisture present in the modules at the time the measurements were made. All leakage currents were within an acceptable level for this type of module.

The rusting of the hardware on the rear side of these modules is similar to that found on modules placed on a rooftop in New York City. The types of pollutants found in the atmosphere in metropolitan areas appear to be much more corrosive or acidic than those found in urban or rural areas.

\subsection{Block II-Model D Modules.}

\subsubsection{First Analysis: 5 Months Exposure.}

\section{Visual}

On both modules a slight seal delamination was found along with tarnish on areas of bared copper on the bus bars. The main collectors of many cells on both modules had become rust colored. Broken surface bubbles were found on one module. Shallow holes with tiny splits running fror them were found in the area between the bus bars and interconnects on both modules; some of these were the result of fallen vendor repair droplets which had fallen off. A hole at the edge seal was found on one module, but no moisture had penetrated the module. 


\section{Electrical}

No significant changes were found during the forward and reverse dark curve measurements or when the high-voltage breakdown tests were performed.

\subsubsection{Second Analysis: 11 Months Exposure}

\section{Visual}

Both modules contained broken surface bubbles. A greenish corrosion was found on the screws located in the rear-side junction box of both modules; on one module an edge crack was noted on a cell on the receiving inspection road map. (The crack appeared to have progressed into the side of one of the interconnects.)

\section{Electrical}

Negligible changes were found on the forward and reverse dark curve measurements. Both modules showed increases in the leakage current in the second six months of exposure. However, all leakage values were well below the design specification of 8 Ha at $1000 \mathrm{~V}$.

\subsubsection{Final Analysis: 48 Months Exposure}

\section{Visual}

The main collectors of all the cells of both modules have changed from white to a rust color. In addition, a spot of delamination, approximately 1/16-inch in diameter, was found on a cell in front of an interconnect on one module.

\section{Electrical}

Forward and reverse dark curve measurements were made and no significant changes were found. High-voltage breakdown tests were performed at 500 and $1000 \mathrm{~V}$, and the changes were negligible.

A comparison of the forward and reverse dark curve measurements as well as the high-voltage breakdown tests performed at receiving inspection and during the first, second, and final analyses can be found in Table 3 . 


\subsubsection{Conclusions}

The slight amount of delamination found between the top of the frame edge and the encapsulant never seemed to have worsened in 48 months of exposure. No traces of moisture seeping into the module from this area were ever found.

The tarnishing of the copper on the bus bars and the discoloration of the main collectors appear to have affected the module performance only from a cosmetic viewpoint.

The broken surface bubbles and the holes left by the missing vendor repair droplets would be unallowable if they extended down to an electrically active part of the module or were a drect pach for molsture to one of chese parts. However, if this were the case, RTV could be used to repair this condition.

The edge crack that was found to have progressed into the side of an. interconnect after 11 months does not appear to have progressed in the subsequent 37 months, and has not affected the electrical performance of the module.

\subsection{Block II-Model B Modules}

\subsubsection{First Analysis: ' 5 Months Exposure}

\section{Visual}

$\Lambda$ ruety diecoloration wao found around a terminal on the top oidc of onc module. Areas of green corrosion were found on both modules on several interconnects and in the terminal areas. This corrosion is believed to have been caused by the acid reaction from a flux residue, not properly removed by the vendor.

Splits found in the hardcoat of both modules were superficial, probably a result of handling or shipping. Delamination was found under an interconnect and around a terminal on one module. A cracked cell, thought to be a deep scratch at the receiving inspection, was found on one module. The crack could cause an open circuit in the cell string. 


\section{Electrical}

No significant changes were found in the forward and reverse dark curve measurements.

\subsubsection{Second Analysis: 11 Months Exposure}

Visual

Twice the number of interconnects covered with green corrosion have been found. An additional split in the hardcoat was found on one module. This is probably a result of handling or shipping.

An additional area of delamination under an interconnect was found on one module. Both modules were found to have newly cracked cells - two on one module and three on the other, one of which was an edge crack.

\section{Electrical}

Little change was found in the forward and reverse dark curve measurement 8 .

\subsubsection{Final Analysis: 48 Months Exposure}

\section{Visual}

The terminals on the rear-side junction box were rusted. One newly cracked cell was found to contain an edge-to-edge crack that could cause an open circuit in the cell string. On one module, a split in the RTV was found in the area between two cells, which extended to the substrate. Delamination was found on the substrate beneath the split, which measured 0.6 -inch in diameter.

Two interconnects on one module were in phase 3 of work hardening, with granulation and a crease across the top of the stress loop. Tarnish was found on areas of bared copper on the interconnects of both modules. Areas of delamination were found on the edge seals of both modules. They ranged in lengths from 0.6 inch to 5.4 inches and in width from 0.1 inch to 0.5 inch. Traces of sand were found to have seeped in under the RTV in these areas also. 
Electrical

No significant changes were found in forward and dark curve measurement s.

NOTE

High-voltage breakdown tests were not performed on Model B modules

as they have a molded glass reinforced polyester substrate.

\subsubsection{Conclusions}

The rusty discoloration found in the terminal area on the top side of one module was probably the result of the reaction of lie encapsulaul material on the metal of the feed-through terminal post. This condition did not appear to affect the electrical capabilities of the module.

The acid reaction of the flux residue on the metal interconnects appeared to worsen with exposure. It is possible that, in time, the acid will erode or weaken the metal. of the interconnect and possibly cause it to break.

The delamination found along the edges of the modules appeared to be progressing inward toward the cell "nests." Evidently, the primer used during manufacturing was either incorrectly applied or the amount used was insufficient to allow the RTV to properly adhere to the substrate. If enough moisture seeps in as far as the cell, it is possible that an electrical problem could ensue.

Further propogation of cracks on the cracked cells was probably caused by diurnal temperature cycling.

As these modules were tested at room temperature, it is not known whether they work electrically at elevated temperatures. Both modules contained one cracked cell that has the potential to cause an open circuit. 


\subsection{Block III-Model C Modules}

\subsubsection{First Analysis: 37 Months Exposure}

Visual

The AR coating on the cells of all four modules had faded or changed to a rust color. On some of the cells the rust was a deeper hue along the grid lines. Areas of exposed copper on the interconnects have become tarnished. This condition was found on the majority of interconnects on the four modules.

Small areas and/or traces of delamination were found in the terminal areas of two of the modules. Delamination was also found along the interconnects in three places on two cells of one module; these areas were approximately 1/16-, 1/32-, and 5/32-inch diameter, respectively. A further spot of delamination, 3/32-inch in diameter, was found along the edge of one cell on one module.

Spots of green corrosion were found on six interconnects of one module; two of these interconnects had been reworked. On a second module, one interconnect was found to have this condition. Some of the heads of the screws in the terminal areas of two of the modules had become slightly rusted. One module was found to have a bubble which had broken at the surface, leaving a shallow hole in the RTV.

\section{Electrical}

Forward and reverse dark curves measurements were not performed on the Block III modules when received at the MP\&T Laboratory because of the large number of modules tested initially, the values of which had changed little or not at all after exposure to the environment. It was decided that these tests could not measure how much a module had degraded and were, therefore, unnecessary. The LAPSS system is believed to be the most suitable instrument to measure power loss, while the measurement of forward and reverse dark curves could reveal wiring errors in a module. 
During the electrical analysis of these four modules, the forward and reverse dark curves measurements were made to see if their values approximated those found for the Block II modules. Typically, the voltage on the forward dark curves at $0.5 \mathrm{amp}$ is on the order of $25 \mathrm{~V}$. Three of the modules were found to be 1.0 to $1.5 \mathrm{~V}$ higher than this value.

On the fourth module, a forward curve could not be obtained because two cells reworked at the factory had been rewired incorrectly. Figure 6 shows that the interconnects from the positive terminals have been attached to the top (negative) side of cell 19, and the interconnects from the bottom (positive) side of cell 19 have been attached to the bottom (positive) side of ceil 27. This caused the loss of one cell from the module string, amounting to a $108 s$ of about $0.3 \mathrm{~V}$. As thls was a uegligible decrease in the. output voltage of the module, the LAPSS I-V curve did not indicate an evident problem.

This problem was visually and electrically overlooked by the source inspectors from JPL as well as the receiving inspectors at MIT LL. Had the forward dark curve been performed initially, this condition would have been discovered. This module was shipped to JPL along with a Problem/Failure Report (PFR) for repair.

High-voltage breakdown tests were performed on the four modules and the leakage currents ranged between 0.15 and 0.29 ua at $1000 \mathrm{~V}$.

\subsubsection{Conclusions}

These Block III Model $C$ modules were found to have most of the conditions found in the Block II generation. With the exception of the miswired cell, there were no conditions found that would affect the electrical performance of these modules. 


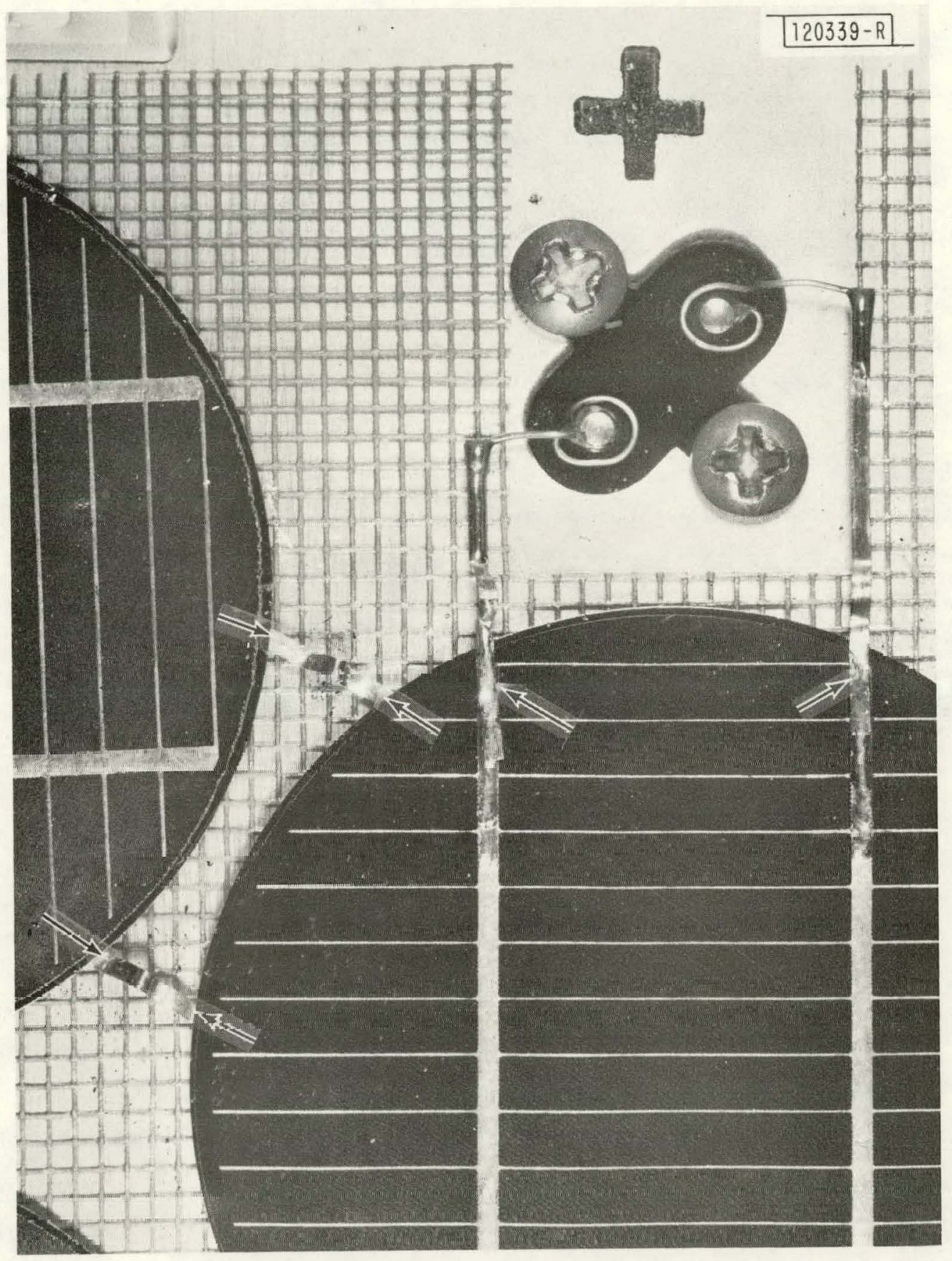

Figure 6. Miswired Block III Model C Ce11. 


\subsection{Block III-Mode1 D Modules}

\subsubsection{First Analysis: 37 Months Exposure}

\section{Visual}

The main collectors of all of the cells on both modules had become stained, changing from white to a rust color. A residue of flux, found on an interconnect in the terminal area, had turned green. On one module a bubble had broken at the surface, leaving a shallow hole in the RTV over a cell.

Bared copper found on an interconnect in the terminal area of one module had become tarnished. This condition was also found along the sheared edges of the terminal strips of both modules. One partially broken interconnect was found between two cells on each module. The remaining interconnects appeared to be in the earlier stages of work hardening. This condition appears to be caused, in part, by poor forming of the stress relief loop. Spots of delamination, approximately $1 / 32$-inch diameter, were found on three cells of one module.

\section{Electrical}

No significant changes were found in the leakage current when the highvoltage breakdown test was performed at 1000 VDC.

\subsubsection{Conclusions}

With the exception of the work-hardening condition, none of the changes noted appear to affect the electrical performance of these modules.

The partially broken interconnects on these modules indicate that these modules will probably tail electrically. This problem is inherent in this generation of Model $\mathrm{D}$ modules, as exemplified by the large number of failures found at the WBNO site in Bryan, Ohio. These modules are not considered to be sufficiently reliable, electrically, to meet the 20-year lifetime goal for PV module as set by DOE. The vendor, informed of this problem, has changed the design of later modules to eliminate this condition. 


\subsection{Block III-Model F Modules}

\subsubsection{First Analysis: 37 Months Exposure}

Visual

The white main collectors on the cells of one module have changed to various shades of brown. As shown on Figure 7, white specks of an unknown residue were found on the foil interconnect around the periphery of the cell area on both modules. Corrosion, from dark green to black, was found on some of the interconnects around the periphery of both modules. A black discoloration was found in areas where the Kapton tape on the foil interconnect was split. Areas of green corrosion were found on the rear-side terminal hardware of one module, as shown on Figure 8 .

The RTV gel, in a corner of one module, had changed from clear to a milky white (see Figure 7). The area of the interconnect beneath this discoloration could not be seen because of the density of the color.

The potting compound used for this type of module is a clear silicone ge1. When a module become hot, the gel softens, often oozing out from the edges of the module. The result is a greasy film on the front and back surfaces of the module. Dirt, normally washed away by rain, adheres to this greasy residue.

Both modules were found to have a black, sooty residue adhering to the front cover glass along the frame edge. This condition was also found along the seam of the tramework on the rear of the module case, as shown on Figure 9. Using a coarse sponge, the modules were washed prior to visual inspection with hot water and Alconox detergent. The cleaning had little effect on the silicone residue except to smear it on the surface of the glass. Isopropyl alcohol was then used repeatedly on the cover glass, until the silicone residue was removed from one module. However, some dirt and silicone did remain on the cover glass of the second module even after repeated cleaning. 


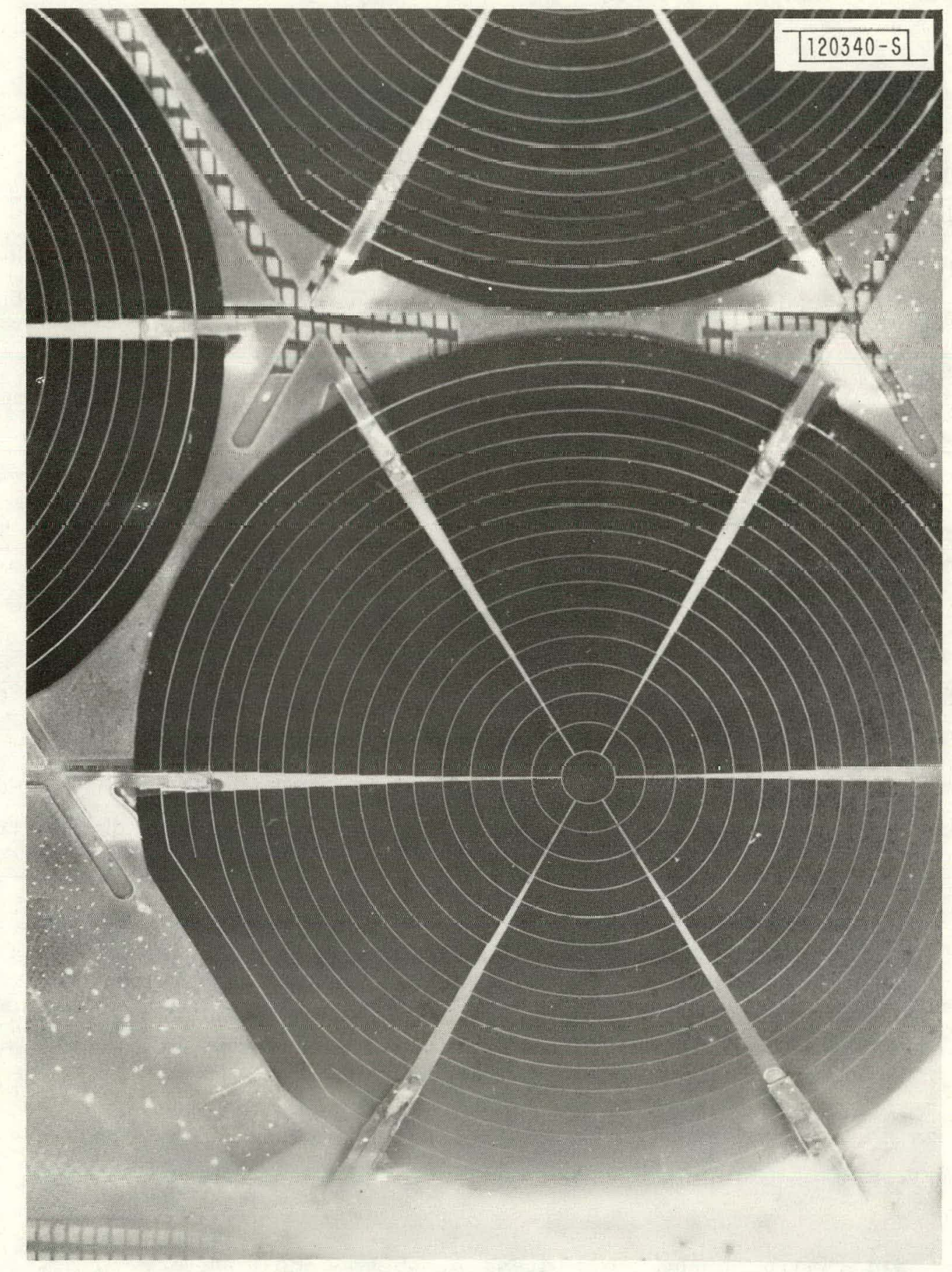

Figure 7. Discoloration of Silicone Gel and Specks of White Residue. 


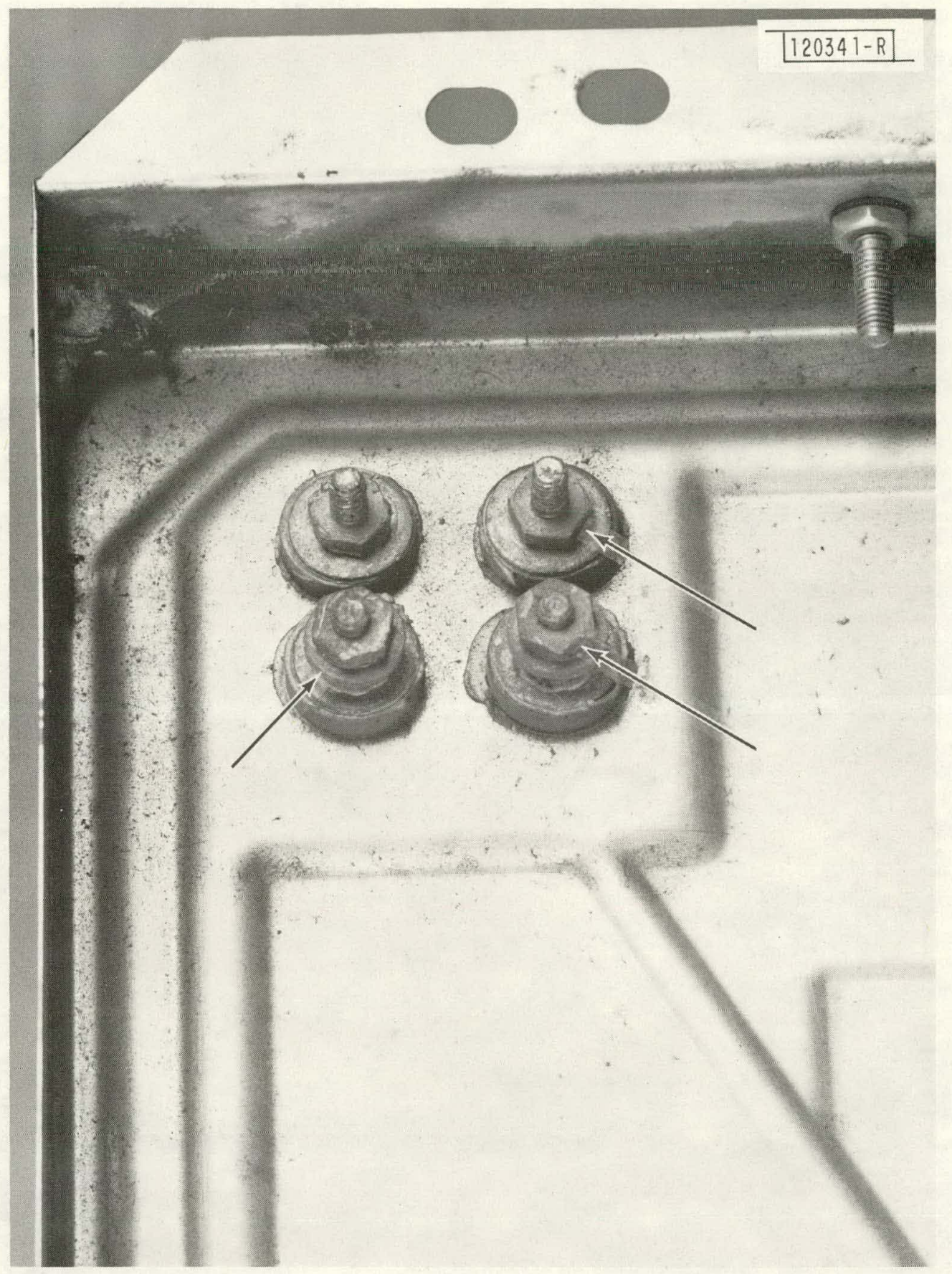

Figure 8. Corrosion on Model F Terminals. 


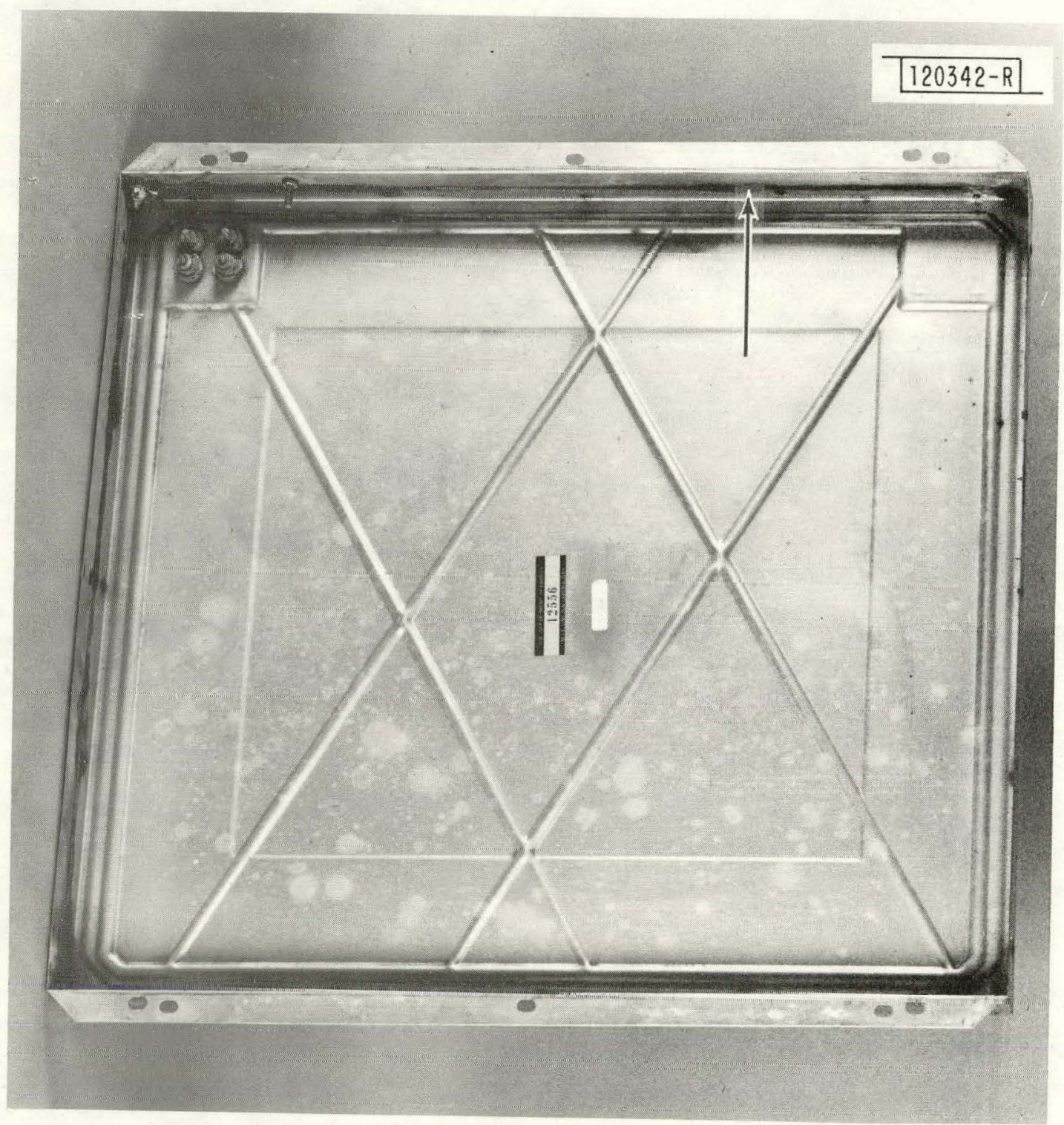

Figure 9. Dirt on Seeping RTV Gel on Model F Module. 


\section{Electrical}

A high-voltage breakdown test was performed at $1500 \mathrm{v}$ for one minute on both modules. The leakage current on the first module ( $/ \mathrm{N}$ 12538) was 23.0 $\mathrm{\mu a}$, exceeding the allowable value of $18 \mathrm{\mu a}$, and thus unacceptable. The leakage current on the second module ( $S / N$ 12556) was also unacceptable; a value of 52.3 ua was obtained.

Both modules were tested in the. LAPSS by the usual method, and a normal I-V curve was obtained for each module. The positive and negative leads were then alternately attached to the grounding screw on the case and the modules were again flashed. The resulting $I-V$ curve, as shown in Figure 10, indicates that some leakage to the case through the positive terminal was present in the first module: On the second module, the $I-V$ curve indicated leakage to the case through the negative terminal. Figure 11 shows the I-V curve when a leakage current through the negative terminal was found. Note the difference in leakage between Figures 10 and 12 .

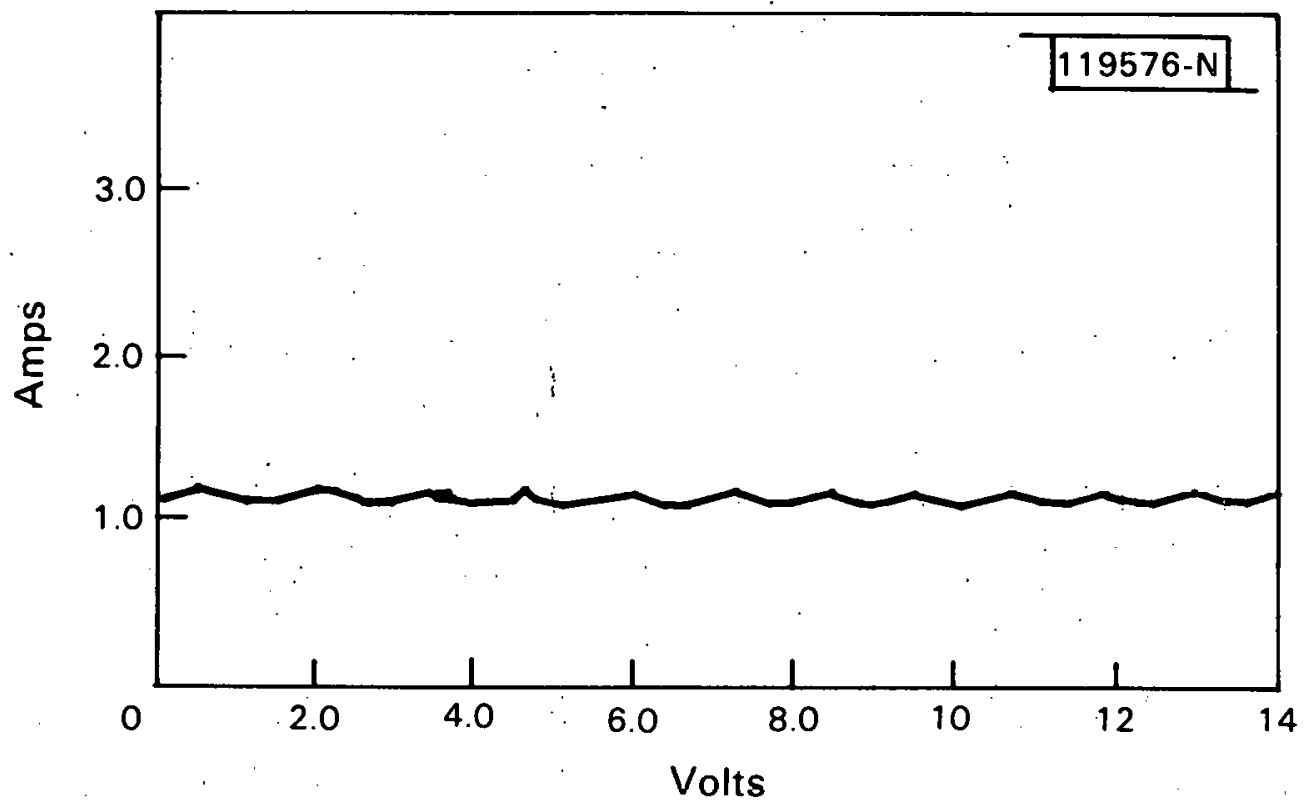

Figure 10. LAPSS Curve Indicating Leakage Current through Positive Terminal. 


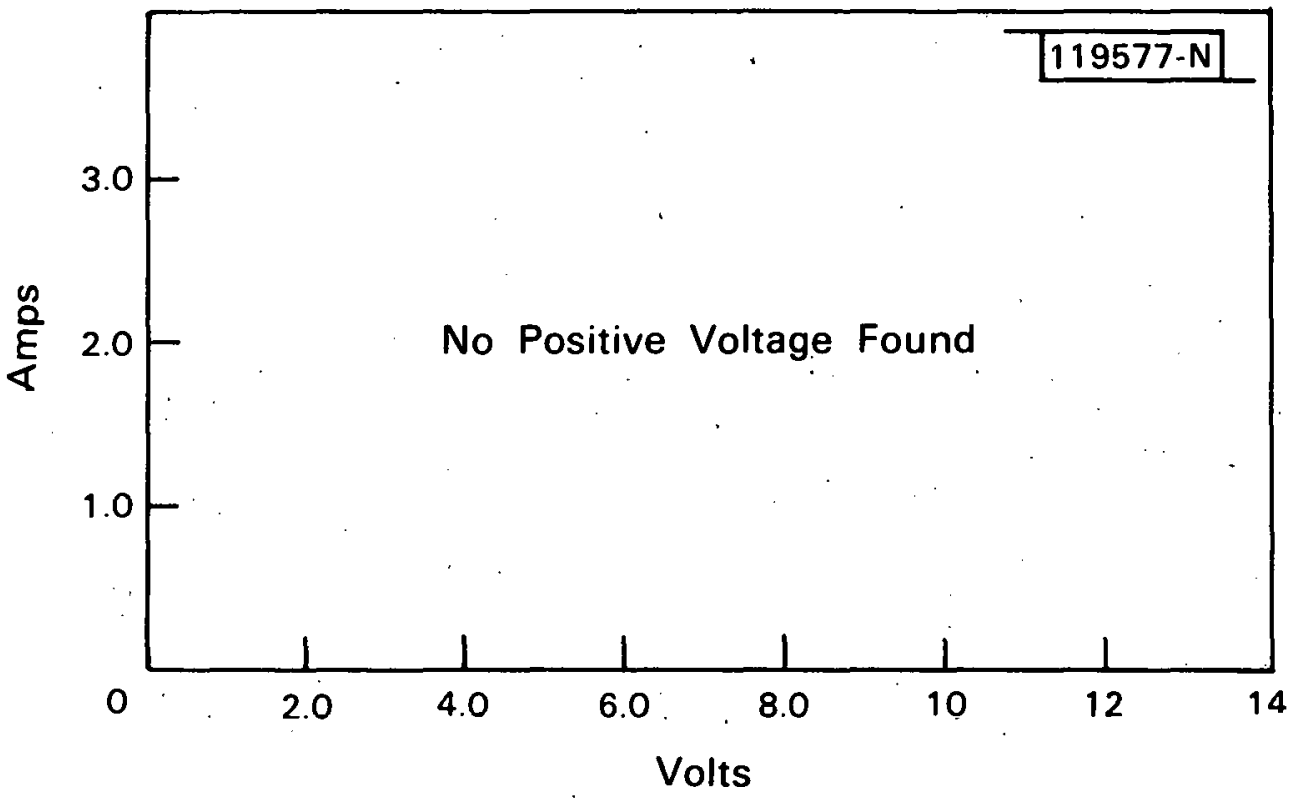

Figure 11. I-V Curve when No Leakage Current Exists between a Terminal and the Case.

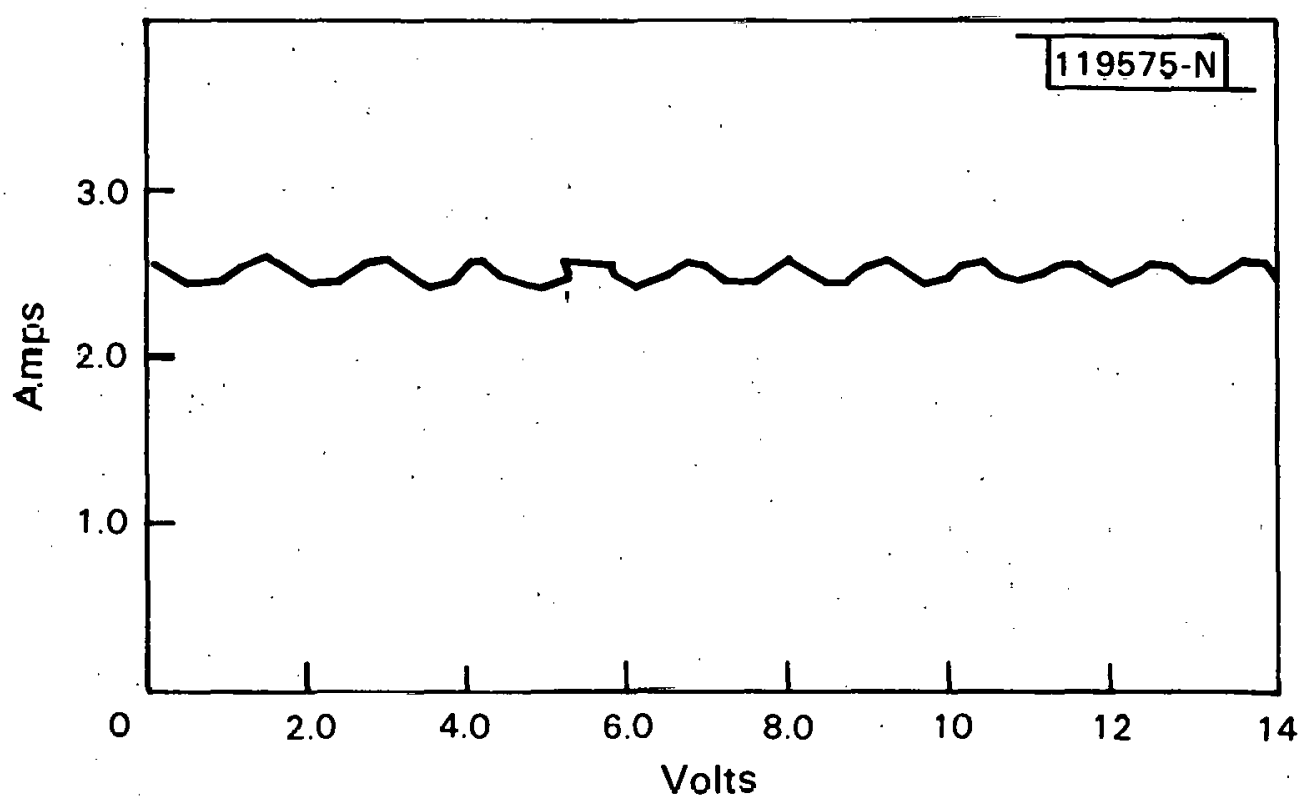

Figure 12. I-V Curve of the Same Module Indicating Leakage Current through Positve Terminal. 


\subsubsection{Conclusions}

The seeping of the RTV gel from beneath the framework of these modules appears to be the result of an insufficient internal seal along the edges of the module case. The fact that the silicone residue on the cover glass captures and holds the dirt, preventing the glass from cleaning itself in the rain, reduces the advantages of having glass-covered modules. An indication of the additional power loss caused by dirty modules can be seen by comparing the peak powers taken from the flash curves of a Model $E$ and a Model F module. When flashed without cleaning, a Model E module had a peak power of 22.6 watts $(\mathrm{W})$; after cleaning, the peak power was $22.7 \mathrm{~W}$, a change of only $0.44 \%$. The Model F modules, when dirty, had a peak power of $21.6 \mathrm{~W}$; after cleaning, the peak power was $23.8 \mathrm{~W}$, an increase of $9.08 \%$.

The most significant problem found in these modules is the high leakage current. It is believed that the Kapton tape used to insulate the foil interconnector blanket had split in places, allowing a path for leakage current to flow to the stainless steel case. In other cases, the foil interconnect had been placed between the top and bottom of the stainless steel case and areas of the interconnect have come in direct contact with the case, causing a dead short. Continuous arcing in these areas caused holes to be burned in the rear side of the stainless steel case, and in some instances, caused the cover glass to shatter because of the intense heat. Many of these modules have already. failed in this manner at NBNM. The vendor no longer manufactures this module and eventually no spares will be available to replace future field failures.

NOTE

As both modules have leakage current in excess of $18.0 \mu \mathrm{a}$, they are considered to be failures and were sent to JPL for final failure analysis. 


\subsection{Block III-Model E Modules}

\subsubsection{First Analysis: 37 Months Exposure}

$\underline{\text { Visual }}$

A slight yellowing of the Tedlar back surface in the area between the cells and the side edges of the frame was found on both modules. Areas of slight discoloration of the grid lines along the edges of 24 cells of one module and 21 cells of the second module were detected. Yellowing of the back surface around the periphery of several cells was found on both modules. Some discoloration along the grid 1 ines of 13 cells was found on one module.

\section{Electrical}

A high-voltage breakdnwn test. was performed at $1500 \mathrm{~V}$ for one minute on both modules. Leakage currents of 0.65 and $0.75 \mu a$, respectively, were found.

\subsubsection{Conclusions}

None of the visual changes noted during degradation analysis appear to have any effect on the electrical performance of these modules after 37 months of field service.

\subsection{Cleaning of Modules}

Initially, modules were flashed without cleaning (as removed from the field), washed with Alconox detergent and hot water, and then flashed after cleaning. The measurement data were used to determine the electrical degradation of a module over an extended period of time.

With the RTV-encapsulated modules it was found that the surface dirt was being impregnated into the RTV, making it more and more difficult to remove. It was then decided to use a fine grade of pumice as an abrasive to remove additional amounts of the impregnated dirt. This method of cleaning was then used, together with Alconox, on all Blocks II and III Models C and D modules. 
A comparison of the peak powers of the modules before cleaning, after cleaning with Alconox, and, where applicable, after cleaning with pumice, can be found in Table 4. The percentage of power receovered is also shown. Photographs of these modules before and after cleaning are shown in Figures 13 through 19.

\begin{tabular}{|c|c|c|c|c|c|c|}
\hline \multirow[b]{2}{*}{ Modules } & $\begin{array}{l}\text { COMPARATIVE TABLE OF PEAX POWERS BEFORE AND AFTER CLEANING } \\
\text { FOR MIT'-CAMBRIDGE MODULES }\end{array}$ & \multicolumn{4}{|c|}{ TABLE 4} & \multirow[b]{2}{*}{$\begin{array}{l}\text { Total } \% \\
\text { Recover- } \\
\text { able Power }\end{array}$} \\
\hline & $\begin{array}{l}\text { Pmax } \\
\text { Dirty } \\
\text { (W) }\end{array}$ & $\begin{array}{l}P_{\max } \\
\text { Cleaned } \\
\text { w/Alconox } \\
\text { (W) }\end{array}$ & $\begin{array}{l}\text { \% Recover- } \\
\text { able Power }\end{array}$ & $\begin{array}{l}P_{\max } \\
\text { Cleaned } \\
\text { W/Pumice } \\
\text { Also } \\
\quad \text { (W) }\end{array}$ & $\begin{array}{c}\text { Additional } \\
\text { \% Recover- } \\
\text { able Power } \\
\text { (W) }\end{array}$ & \\
\hline Model A (Block I) & $\begin{array}{l}4.55 \\
4.71\end{array}$ & $\begin{array}{l}4.73 \\
4.80\end{array}$ & $\begin{array}{l}3.81 \\
1.88\end{array}$ & - & - & $\begin{array}{l}3.81 \\
1.88\end{array}$ \\
\hline Model C (Block II) & $\begin{array}{l}7.63 \\
7.08\end{array}$ & $\begin{array}{l}7.53^{*} \\
8.49\end{array}$ & 16.61 & $\begin{array}{l}9.97 \\
9.69\end{array}$ & 12.38 & $\begin{array}{l}23.47 \\
26.93\end{array}$ \\
\hline Model D (Block II) & $\begin{array}{l}15.48 \\
15.27\end{array}$ & $\begin{array}{l}20.27 \\
18.63\end{array}$ & $\begin{array}{l}23.63 \\
18.03\end{array}$ & $\begin{array}{l}21.94 \\
22.15\end{array}$ & $\begin{array}{r}7.61 \\
15.89\end{array}$ & $\begin{array}{l}29.44 \\
31.06\end{array}$ \\
\hline Model B (Block II) & $\begin{array}{l}23.93 \\
26.05\end{array}$ & $\begin{array}{l}26.25 \\
28.55\end{array}$ & $\begin{array}{l}8.84 \\
8.76\end{array}$ & 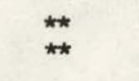 & $\overline{-}$ & $\begin{array}{l}8.84 \\
8.76\end{array}$ \\
\hline Model C (Block III) & $\begin{array}{l}7.50 \\
8.03 \\
7.44 \\
7.15\end{array}$ & $\begin{array}{l}9.56 \\
9.95 \\
9.50 \\
8.98\end{array}$ & $\begin{array}{l}21.55 \\
19.30 \\
21.68 \\
20.38\end{array}$ & $\begin{array}{r}10.15 \\
10.70 \\
10.03 \\
9.77\end{array}$ & $\begin{array}{l}5.81 \\
7.01 \\
5.28 \\
8.09\end{array}$ & $\begin{array}{l}26.11 \\
24.96 \\
25.82 \\
26.82\end{array}$ \\
\hline Model D (Block III) & $\begin{array}{l}15,77 \\
15.94\end{array}$ & $\begin{array}{l}20.12 \\
19.27\end{array}$ & $\begin{array}{l}21.62 \\
17.28\end{array}$ & $\begin{array}{l}21.43 \\
20.81\end{array}$ & $\begin{array}{l}6.11 \\
7.40\end{array}$ & $\begin{array}{l}35.89 \\
23.40\end{array}$ \\
\hline Model F (Block III) & $\begin{array}{l}21.64 \\
21.98\end{array}$ & $\begin{array}{l}23.80 \\
23.71\end{array}$ & $\begin{array}{l}9.08 \\
7.30\end{array}$ & - & $\overline{-}$ & $\begin{array}{l}9.08 \\
7.30\end{array}$ \\
\hline Model E (Block II) & $\begin{array}{l}22.62 \\
23.03\end{array}$ & $\begin{array}{l}22.74 \\
23.58\end{array}$ & $\begin{array}{l}0.53 \\
2.33\end{array}$ & - & - & $\begin{array}{l}0.53 \\
2.33\end{array}$ \\
\hline $\begin{array}{l}\text { * This value may ha } \\
\text { * Model B modules ha } \\
\text { scratch the surfac }\end{array}$ & $\begin{array}{l}\text { con } \\
\text { this }\end{array}$ & $\begin{array}{l}\text { coating } \\
\text { coat, wa }\end{array}$ & $\begin{array}{l}\text { ction when } t \\
\text { yed on the } t \\
\text { used. }\end{array}$ & dule was & $\begin{array}{l}\text { shed. } \\
\text { Pumice, be }\end{array}$ & it would \\
\hline
\end{tabular}




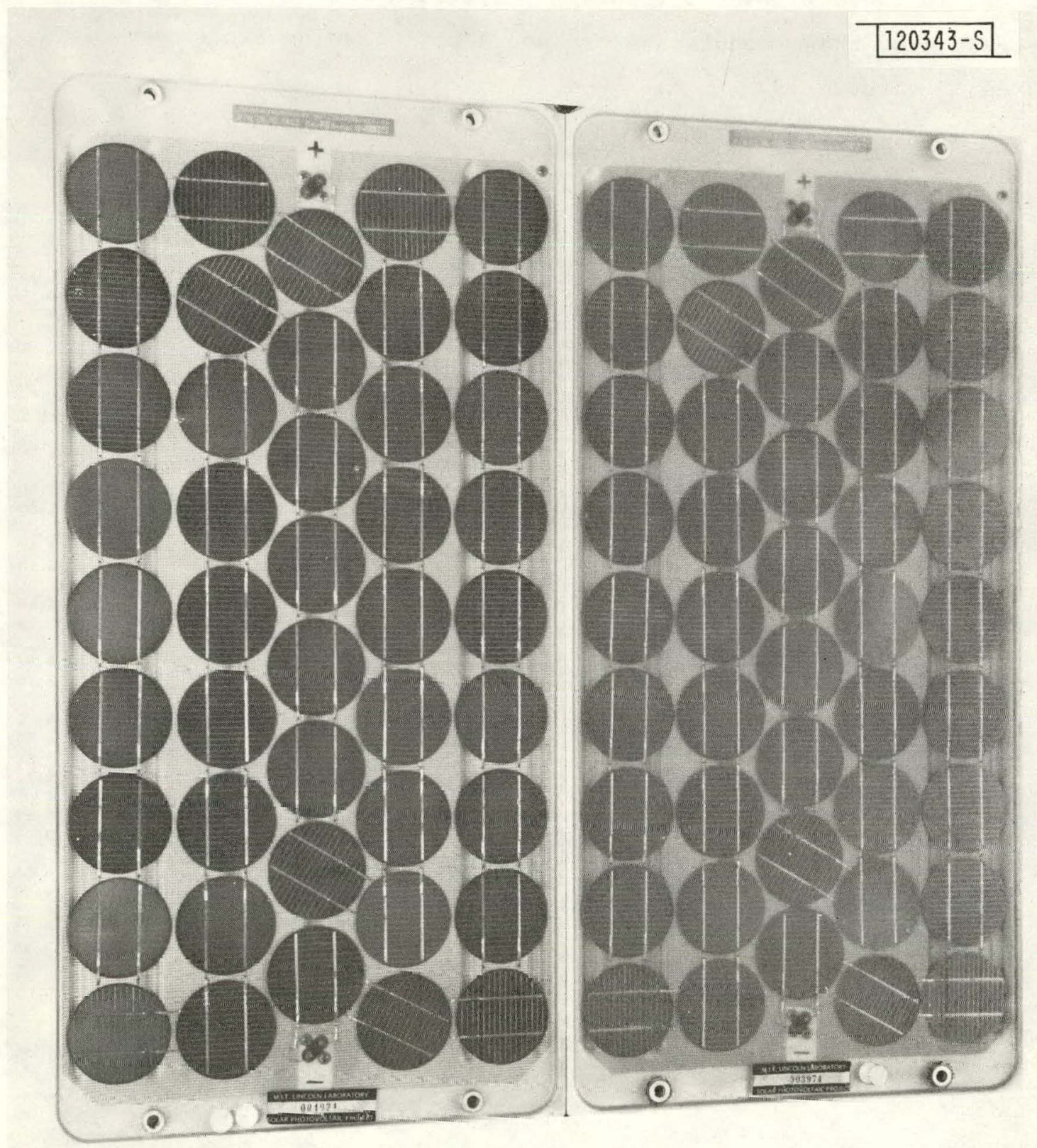

Figure 13. Model $\mathrm{C}$, before and after Cleaning (Block II). 


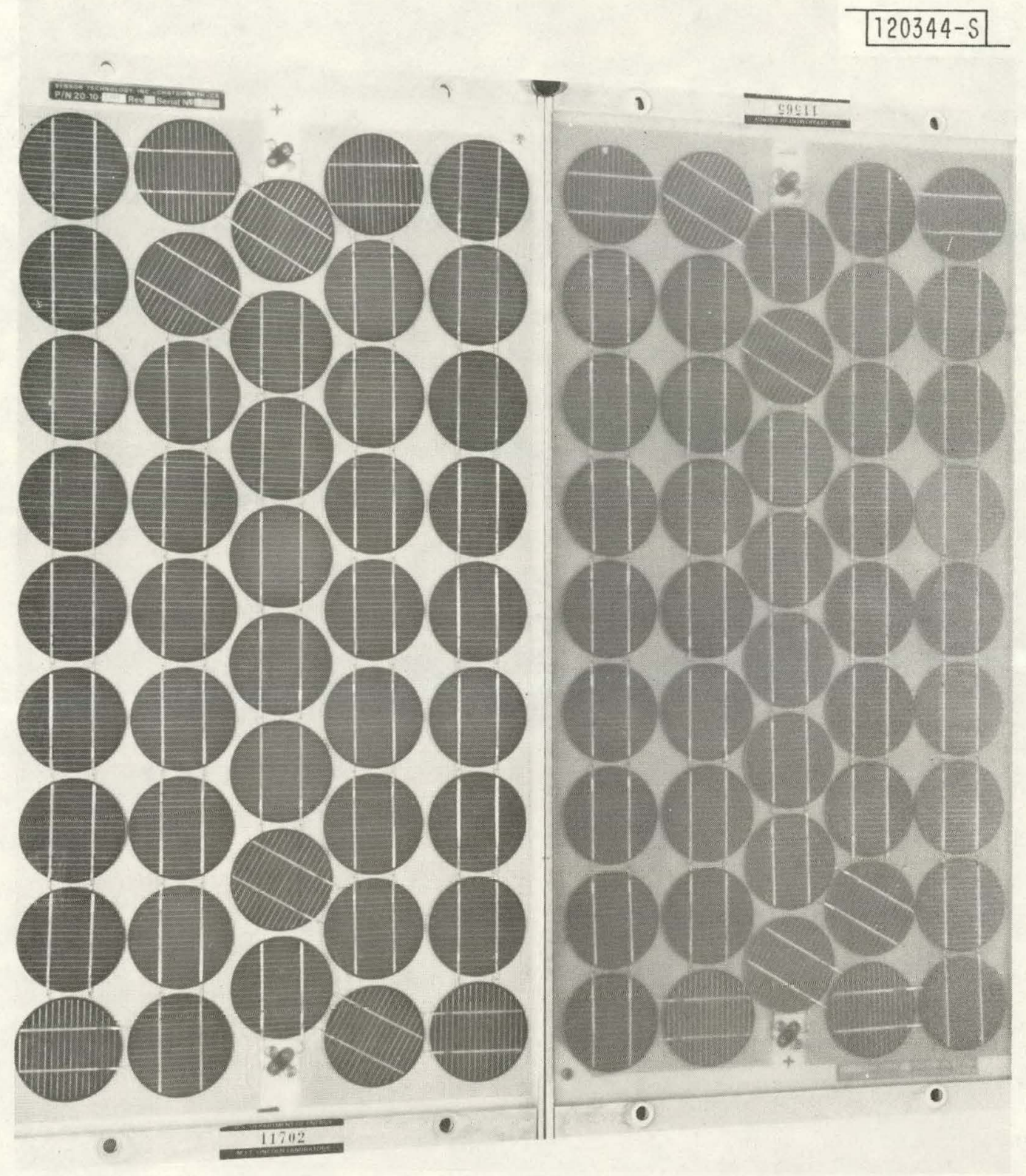

Figure 14. Mode1 C, before and after Cleaning (Block III). 


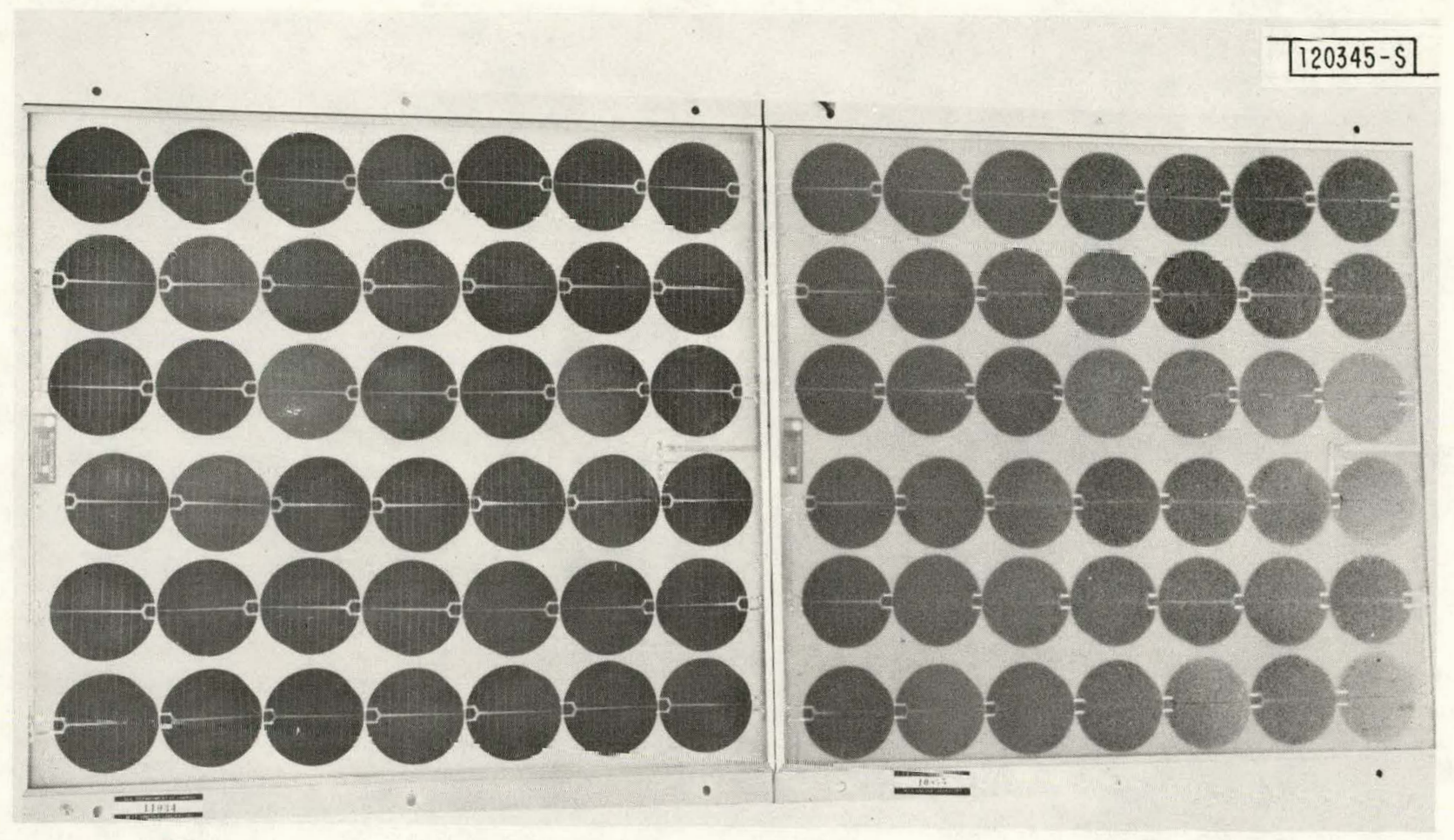

Figure 15. Model D, before and after Cleaning (Block II). 


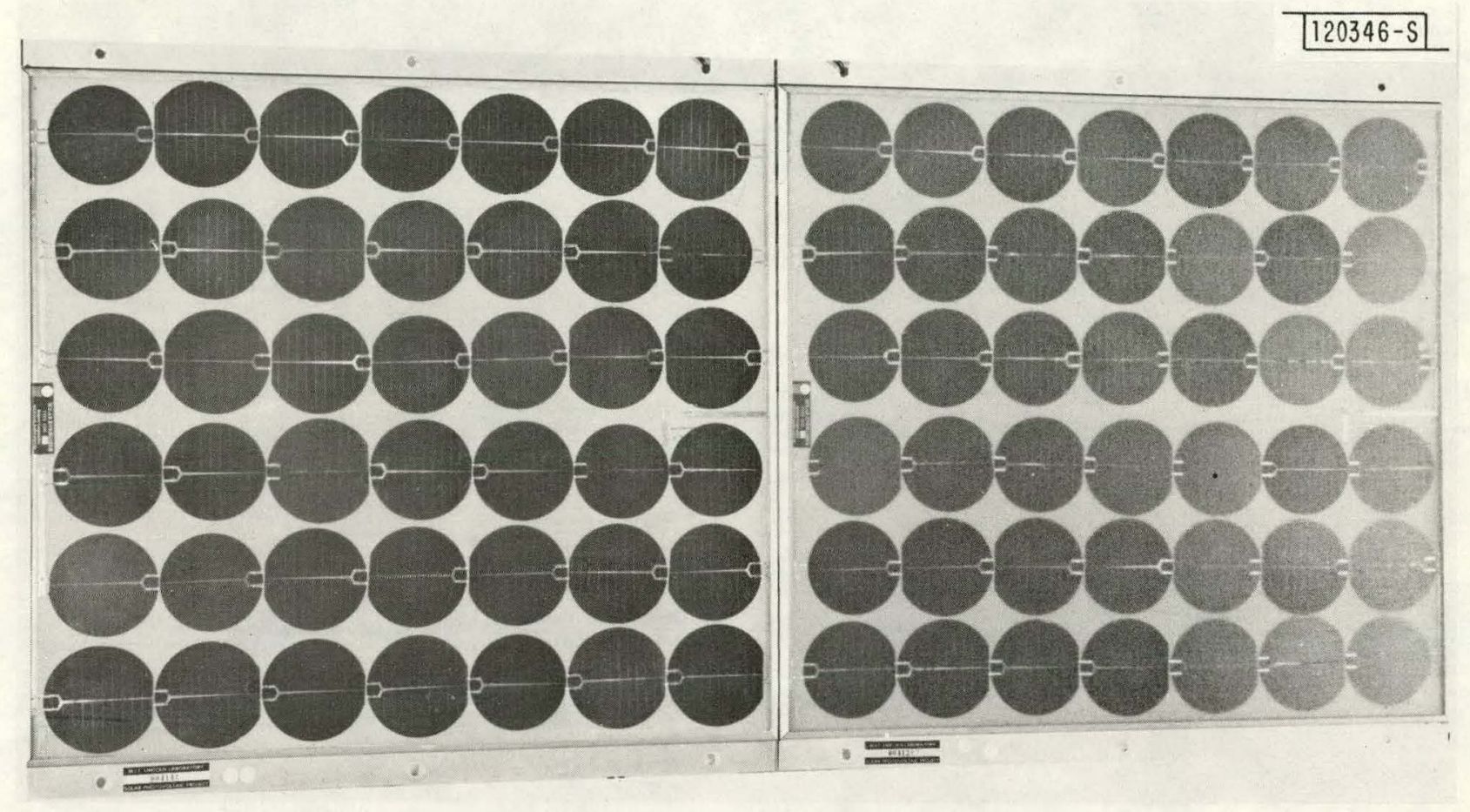

Figure 16. Model D, before and after Cleaning (Block III). 


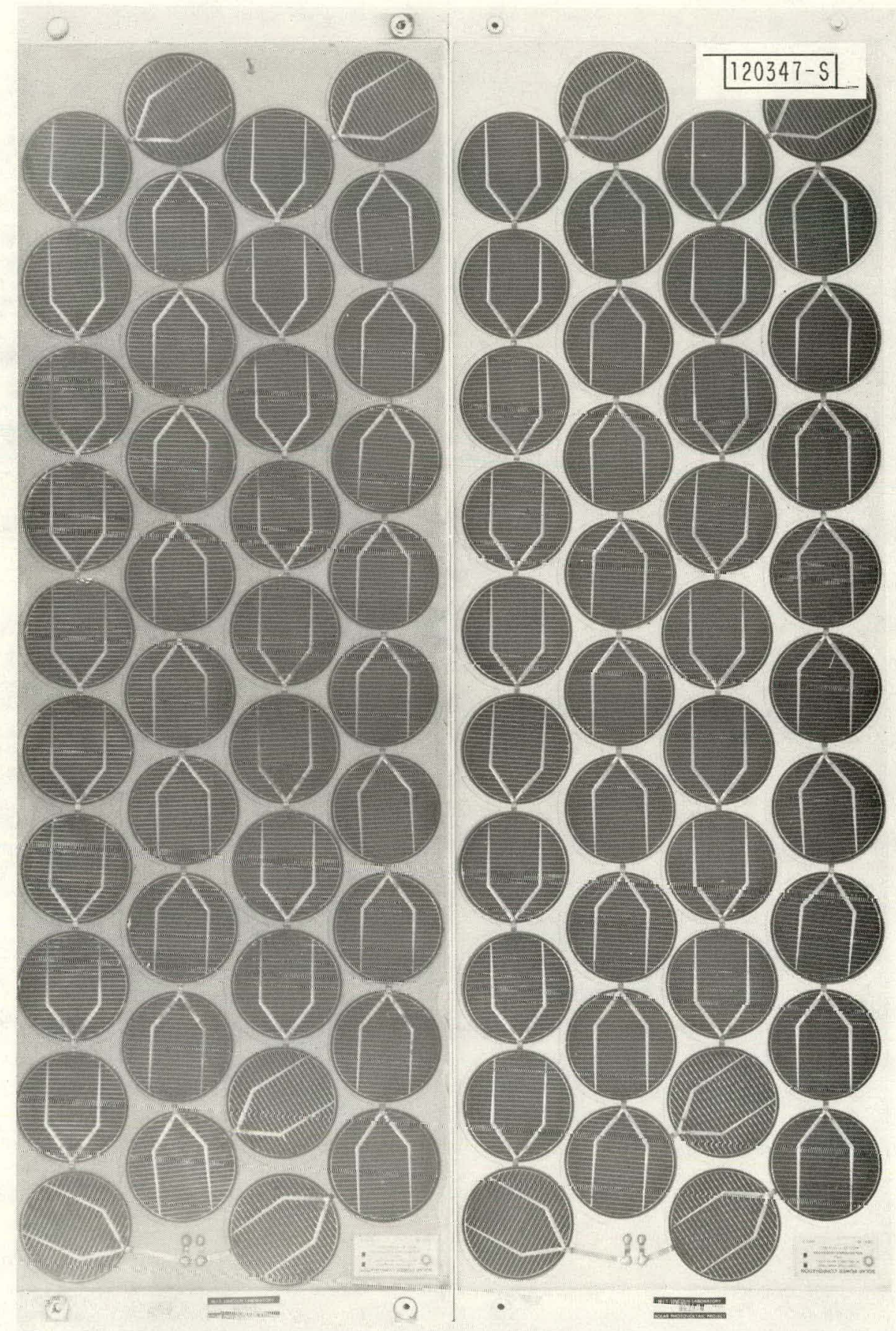

Figure 17. Model B, before and after Cleaning (Block II). 


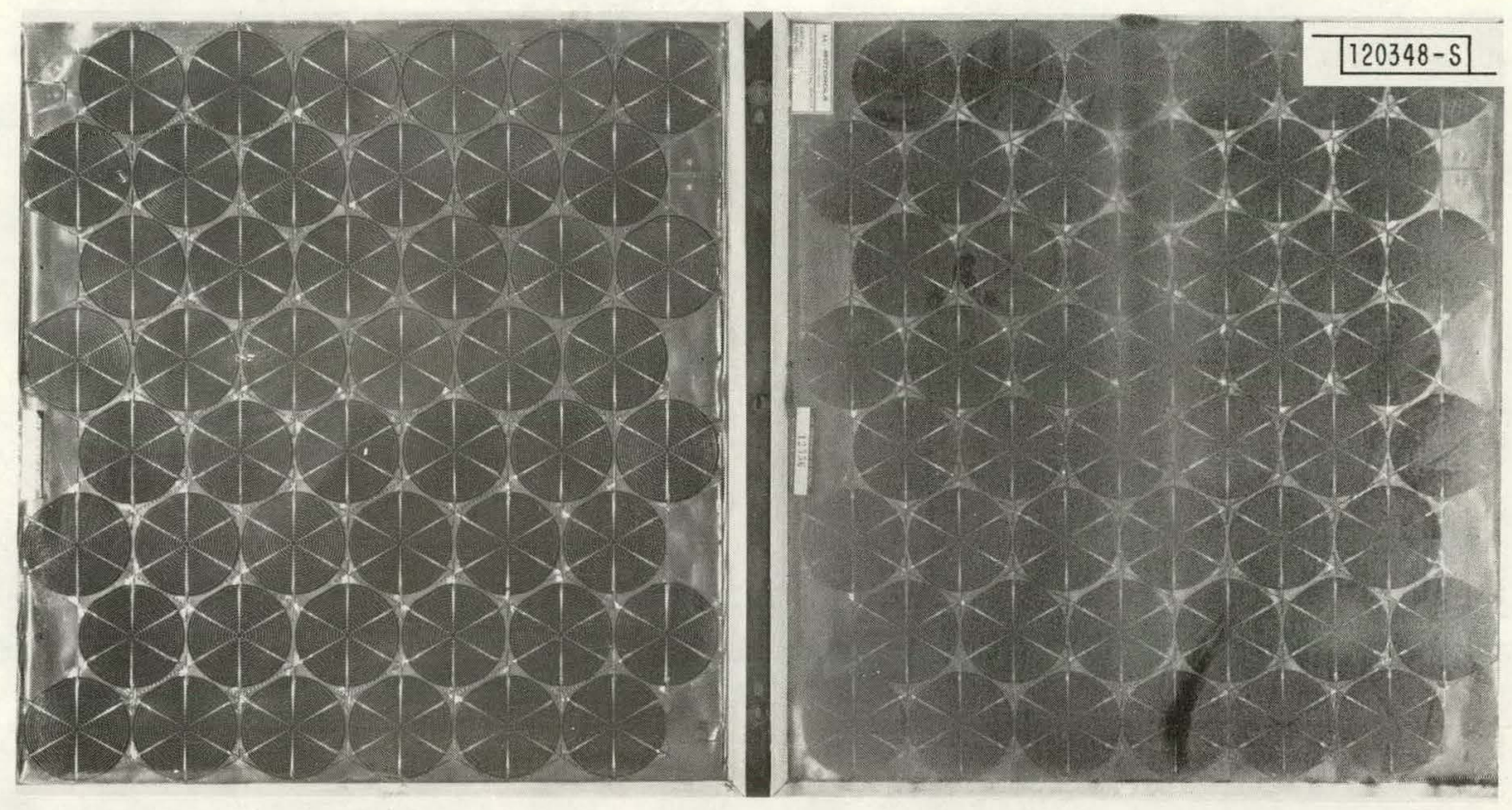

Figure 18. Model F, before and after Cleaning (Block II). 


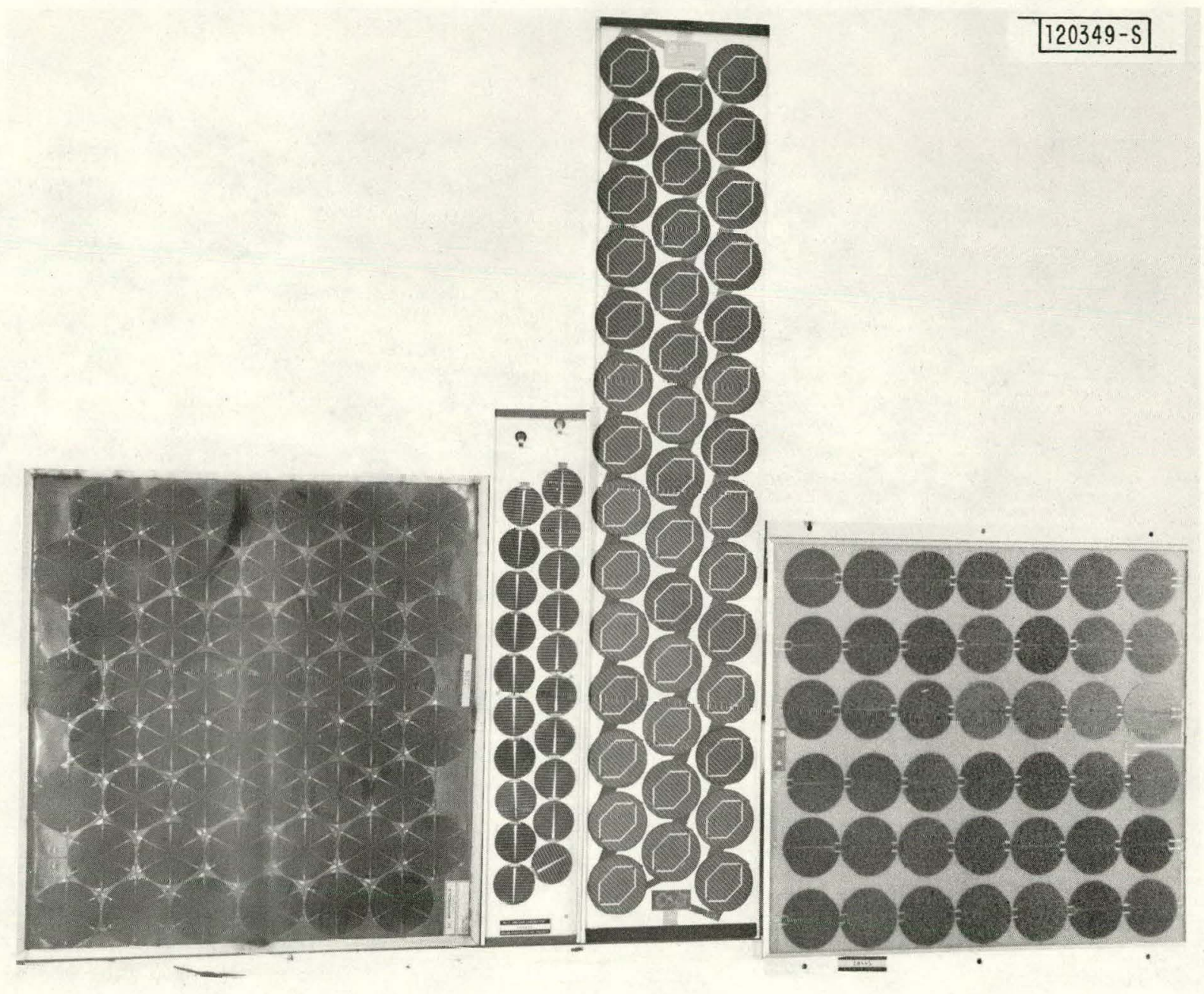

Figure 19. Models A (Block I), D (Block III), E (Block III), and F (Blnck III), before Cleaning. 


\section{MEAD, NEBRASKA, AGRICULTURAL EXPERIMENT}

On 17 September 1981, at the Mead, Nebraska, test site, 12 Model $\mathrm{C}$ and 12 Model $D$ Block II modules were removed from the two designated degradation frames and returned to the MP\&T Laboratory for final degradation analysis. These modules had been returned to the MP\&T Laboratory twice previously for visual and electrical degradation analysis. Six of the Model $\mathrm{C}$ modules had been exposed for 44 months and $s i x$ had been exposed for 46 months. All Model D modules had been exposed for 44 months.

\subsection{Block II-Model C Modules}

\subsubsection{Visual}

The discoloration of the AR coating had worsened from that found on earlier analyses. Initially this discoloration was found mainly on the grid lines; it was subsequently determined that this condition was caused by the migration of tin from the solder on the grids into the AR coating. With time the discoloration has continued to spread, making it difficult to detect either new or old cracked cells. Now most of the AR coating on most of the cells has become discolored.

To discover whether the discoloration of the AR coating diminished the electrical performance of the cells, it would be necessary to obtain I-V curves on each cell prior to exposure, and, after time and cleaning the RTV to its original state, repeating the $I-V$ curve measurements and comparing the two sets of $I-V$ curves. At present, it is difficult to determine the amount of electrical degradation this condition may cause because all measurements are made at the module level.

Areas of delamination were found on two modules adjacent to the interconnects on a cell. On one module two cells were affected with delamination areas of 1/16-inch and 3/16-inch diameter. On the other module one cell was affected, with a delamination area of 5/32 inch. In addition, 
four modules were found to have delamination in the positive and/or negative terminal areas; these areas ranged from being barely perceptible to 3/32-inch wide.

A surface bubble had broken, leaving a shallow hole in the RTV over a cell on one module. Seven cells on one module had tarnish on their metal grids. A surface split in the RTV, measuring $1 / 16-$ inch long by $1 / 32-$ inch deep was found over a cell on one module. A residue of flux that had turned green was found on a bus wire connection in the positive terminal area of one module.

Shore hardness measurements have been made since August 1978 to determine degradation of the encapsulant. In a prior analysis the Shore hardness of the RTV of eight modules with 14 months exposure ranged from 38 to 49 points. When measured again after an additional 30 months of field service, the hardness of the encapsulant ranged from 43 to 51 points. In another measurement, four modules with 16 months exposure were found to have a Shore hardness ranging from 40 to 49 points. With an additional 30 months exposure these same modules were found to have a Shore hardness of 42 to 52 points. So far, the measurement of Shore hardness has not provided any meaningful indication of encapsulant degradacton.

One major problem with Block II Model $\mathrm{C}$ modules has been cracked cells. In the past, cracked cells have been categorized by the cause and/or location of the crack. Typically, at recelving inspection, edge cracks and randon cracks were found.

During the first analysis of these modules, after two to eight months of field service; four cracked cells were found on two modules. These cells had cracked in the area of the cell that sits over the structural ribs of the substrate pan. It was found that when the temperature increased, the thickness of the RTV in the ribs expanded more than the thlckutss of Llie RTV on the flat metal surface adjacent to the ribs, causing an uneven pressure to be applied to the backs of the cells, sometimes resulting in the cell becoming cracked. This type of crack was called a rib crack. 
These same modules were again returned to the MP\&T Laboratory in January 1979, after 12 additional months exposure. Twelve newly cracked cells were found on nine of the modules. One module contained a cell that had cracked at random. An edge crack was found on one cell of another module. Four modules were found to contain one cell with rib cracks.

of the six remaining modules, each contained one cell that appeared to have been cracked by impact. The impact area on a cell was generally cracked in an irregular circular manner, with radial cracks emanating from the impact area toward the edges of the cell. These cells had been damaged by a hailstorm that had struck the array in May 1978. This type of crack was called an impact crack.

After an additional 30 months exposure, these modules were returned to the MP\&T Laboratory, for the third time. At present, all twelve modules contain at least one cracked cell. On five of these modules, an additional five cells were found to have cracked over a rib.

Seventeen new impact-cracked cells were found on ten of the modules. The increase in the number of impact-cracked cells is believed to be due to a second hailstorm which struck the array in June 1981 .

\subsubsection{Electrical}

When received at the MP\&T Laboratory, all modules were flashed in the LAPSS without cleaning. The I-V curves were obtained for the twelve modules showing the open-circuit voltages to be ranging from 24.07 to $25.10 \mathrm{~V}$ and the short-circuit currents to be between 0.45 and 0.52 amp. The peak powers ranged from 5.91 to $9.80 \mathrm{~W}$. The modules were then washed with Alconox and hot water, rinsed in hot water, abraded with pumice, and then rinsed with hot water.

To determine the amount of power to be recovered by cleaning, the modules were again flashed in the LAPSS. Increases in the peak powers were found from $9.15 \%$ to $22.4 \%$. 
NOTE

Although one of the modules showed an increase of $46.71 \%$, this is considered anomalous because of the numerous cracked cells found, which might have given an incorrect output when initially tested.

The percentage of increased power was recalculated based on the shortcircuit current values (clean and dirty), and increases from $8.16 \%$ to $23.33 \%$ were found. The results of the LAPSS tests and the percentage of increase in both the peak powers and short-circuit currents can be found in Table 5 .

The shape of the I-V curve can reveal problems at the cell level. Six of the curves obtained for these modules were somewhat irregular in shape. Figure 20 is an example of a slightly irregular-shaped curve obtained from a module prior to cleaning. Figure 21 is an $I-V$ curve of the same module after washing. The irregular shape above the knee of the curve is more pronounced in Figure 21, indicating the probable presence of one or more cracked cells. The shape of the curve was probably made more pronounced due to the pressure applied to the damaged cell during washing.

Forward and reverse dark curve measurements were made on each of the twelve modules. When last measured, the voltage on the forward dark curve at $0.5 \mathrm{amp}$ was between 26.0 and $26.5 \mathrm{~V}$. Five of the modules were found to have increased $0.5 \mathrm{~V}$, six modules were the same, and one module had a decrease of $0.5 \mathrm{~V}$.

The reverse dark curve measurement is made with a constant voltage of $160 \mathrm{~V}$; all modules increased in value from 0.06 to 0.31 ma over the previous méasurements.

A high voltage breakdown test was performed at 1000 VDC for one minute. Leakage currents $\left(I_{1}\right)$ ranging from 0.16 to 0.68 pa were found. These values were all less than those recorded at receiving inspection.

The results of the forward and reverse dark curve measurements and leakage currents noted at the receiving inspection and after $2,6,8,14$, 16, 44, and 46 months of field service are shown on Table 6. 


\begin{tabular}{|c|c|c|c|c|c|c|c|c|}
\hline : & . & . & $\begin{array}{r}\text { BLOC } \\
\text { COMPARA' } \\
\text { BEFO }\end{array}$ & $\begin{array}{l}\text { TABLE } \\
\text { II MODEL } \\
\text { VE TABLE } \\
\text { E AND AFT }\end{array}$ & $\begin{array}{l}\text { MODULE } \\
\text { LAPSS } \\
\text { CLEANI }\end{array}$ & $\begin{array}{l}\text { ESULTS } \\
\text { S. }\end{array}$ & & \\
\hline \multirow[b]{2}{*}{ LL $S / \pi$} & \multicolumn{3}{|c|}{ Dirty } & \multicolumn{3}{|c|}{ Clean } & \multirow[b]{2}{*}{$\begin{array}{c}P_{\max } \\
(\% \text { increased })\end{array}$} & \multirow[b]{2}{*}{$\begin{array}{c}\mathrm{I}_{\text {sc }} \\
(\% \text { increase })\end{array}$} \\
\hline & $\begin{array}{c}v_{o c} \\
(\text { volts) }\end{array}$ & $\begin{array}{l}\mathrm{I}_{\text {sc }} \\
\text { (amps) }\end{array}$ & $\begin{array}{c}P_{\max } \\
\text { (watts) }\end{array}$ & $\begin{array}{c}v_{o c} \\
\text { (volts) }\end{array}$ & $\begin{array}{c}I_{s c} \\
\text { (amps) }\end{array}$ & $\begin{array}{l}P_{\max } \\
\text { (watts) }\end{array}$ & & \\
\hline $3565(46) *$ & 24.95 & 0.52 & 9.80 & 24.95 & 0.60 & 11.37 & 13.81 & 13.33 \\
\hline $3559(44)$ & 25.07 & 0.49 & 9.19 & 25.05 & 0.62 & 10.92 & 15.84 & 20.97 \\
\hline $3568 \quad(44)$ & 24.90 & 0.47 & 7.45 & 24.80 & 0.61 & 8.81 & 15.44 & 22.95 \\
\hline $3525(44)$ & 24.07 & 0.46 & 7.98 & 24.10 & 0.60 & 10.29 & 22.45 & 23.33 \\
\hline $2746 \quad(44)$ & 25.10 & 0.45 & 8.54 & 25.10 & 0.49 & 9.40 & 9.15 & 8.16 \\
\hline $27 ? 8(44)$ & 24.98 & 0.51 & 9.68 & 25.00 & 0.59 & 10.91 & 11.27 & 13.56 \\
\hline $3713(46)$ & 24.86 & 0.52 & 9.57. & 25.11 & 0.61 & 11.50 & 16.78 & 14.75 \\
\hline $3917(46)$ & 24.94 & $c .49$ & 9.36 & 25.42 & 0.60 & 11.09 & 15.60 & 18.33 \\
\hline $2734(46)$ & 24.95 & $c .48$ & 7.92 & 24.93 & 0.58 & 9.19 & 13.82 & 17.24 \\
\hline $2736(46)$ & 24.55 & c. .50 & 8.74 & 24.62 & 0.60 & 10.45 & 16.36 & 16.67 \\
\hline $3737(46)$ & 24.44 & 0.48 & 9.00 & 24.60 & 0.60 & 11.09 & 18.85 & 20.00 \\
\hline $3739(46)$ & 24.84 & 0.48 & 5.91 & 25.00 & 0.54 & 11.09 & 46.71 & 11.11 \\
\hline
\end{tabular}




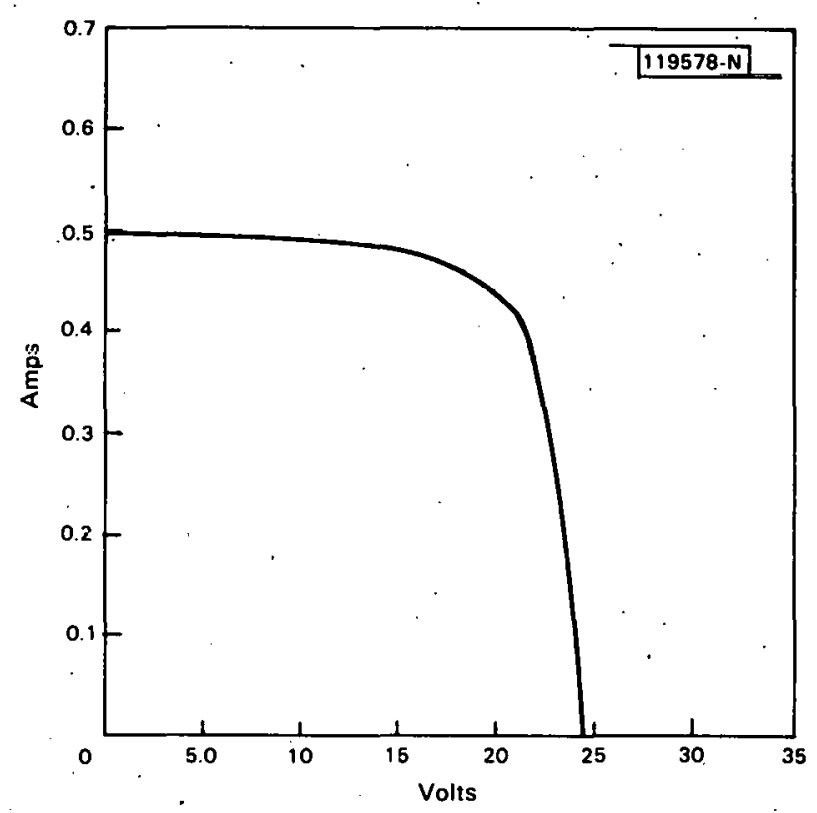

Figure 20. I-V Curve, Model A, before Cleaning.

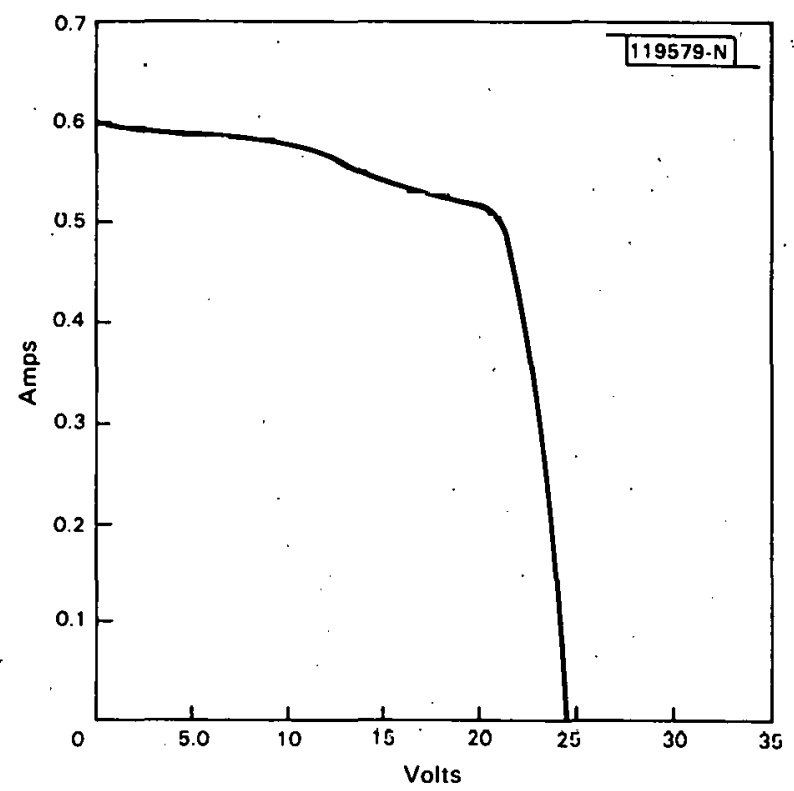

Figure 21. I-V Curve, Model A, after Cleaning. 
TABLE 6

MODEL C BLOCK II:

COMPARATIVE TABLE OF FORWARD AND REVERSE DARK CURVES AND HIGH-VOLTAGE LEARAGE CURRENTS

\begin{tabular}{|c|c|c|c|c|c|c|c|c|c|}
\hline Module & & $\begin{array}{l}\text { Forward } \\
\text { Dark } \\
\text { (V) }\end{array}$ & $\begin{array}{c}\text { Reverse } \\
\text { Dark. } \\
\text { (ma) }\end{array}$ & $\begin{array}{c}I_{\ell} a t \\
1000 \mathrm{~V} \\
\left(\mu_{a}\right)\end{array}$ & Module & & $\begin{array}{l}\text { Forward } \\
\text { Dark } \\
\text { (V) }\end{array}$ & $\begin{array}{c}\text { Reverse } \\
\text { Dark } \\
\text { (ma) }\end{array}$ & $\begin{array}{c}I_{\ell} a t \\
1000 V \\
(\mu a)\end{array}$ \\
\hline 2738 & A & 26.0 & 9.9 & 0.50 & $3917 *$ & A & 24.5 & 14.0 & 0.72 \\
\hline 2 mos & B & 25.5 & 10.0 & 0.18 & $6 \mathrm{mos}$ & B & 26.0 & 13.5 & 0.31 \\
\hline $14 \mathrm{mos}$ & C & 26.5 & 9.6 & 0.15 & $16 \mathrm{mos}$ & C & 26.5 & 12.5 & 0.28 \\
\hline $44 \mathrm{mos}$ & D & 26.5 & 8.9 & 0.29 & $46 \mathrm{mos}$ & D & 26.0 & 9.5 & 0.42 \\
\hline $2746 *$ & A & 25.5 & 8.4 & 0.80 & $3713 *$ & A & 26.0 & 15.9 & 0.90 \\
\hline 2 mos & B & 25.5 & 8.4 & 0.13 & $6 \mathrm{mos}$ & B & 26.5 & 17.0 & 0.41 \\
\hline $14 \operatorname{mos}$ & C & 26.5 & 7.8 & 0.10 & 16 mos & C & 26.0 & .10 .2 & 0.38 \\
\hline 44 mos & D & 26.5 & 7.2 & 0.16 & $46 \mathrm{mos}$ & D & 26.5 & 14.0 & 0.67 \\
\hline 3525 & A & 25.0 & 22.0 & 0.85 & $3739 *$ & A & 24.5 & 45.0 & 1.28 \\
\hline $8 \cdot \operatorname{mos}$ & B & 25.5 & 22.0 & 0.62 & $6 \mathrm{mos}$ & B & 26.5 & 40.0 & 0.30 \\
\hline 14 mos & C & 26.0 & 21.0 & 0.37 & 16 mos & C & 26.5 & 43.0 & 0.25 \\
\hline $44 \mathrm{mos}$ & D & 26.0 & 20.0 & 0.64 & $46 \mathrm{mos}$ & D & 27.0 & 40.0 & 0.44 \\
\hline $3559 *$ & A & 25.5 & 9.2 & 0.79 & $3737 *$ & A & 24.0 & 11.0 & 0.80 \\
\hline 8 mos & B & 26.0 & 9.5 & 0.35 & $6 \mathrm{mos}$ & B & 25.5 & 11.0. & 0.32 \\
\hline $14 \mathrm{mos}$ & C & 26.5 & 9.2 & 0.23 & $16 \mathrm{mos}$ & C & 26.5 & 15.8 & 0.24 \\
\hline $44 \mathrm{mos}$ & D & 26.5 & 9.0 & 0.39 & $46 \mathrm{mos}$ & D & 27.0 & 11.0 & 0.55 \\
\hline $3565 *$ & A & 25.5 & 16.0 & 1.10 & $2736 *$ & A & 25.5 & 11.2 & 0.50 \\
\hline 8 mos & B & 26.0 & 16.0 & 0.51 & $2 \mathrm{mos}$ & B & 25.5 & 12.0 & 0.22 \\
\hline $14 \operatorname{mos}$ & C & 26.5 & 15.5 & 0.34 & $14 \mathrm{mos}$ & C & 26.0 & 11.4 & 0.19 \\
\hline $44 \operatorname{mos}$ & D & 26.5 & 14.5 & 0.65 & 44 mos & D & 26.5 & 10.2 & 0.26 \\
\hline $3568^{\star}{ }^{\prime}$ & A & 25.5 & 10.8 & 0.99 & $2734 *$ & A & 26.0 & 16.0 & 1.0 \\
\hline $8 \operatorname{mos}$ & B & 26.0 & . 11.3 & 0.58 & $2 \mathrm{mos}$ & B & 26.0 & 16.0 & 0.21 \\
\hline $14 \mathrm{mos}$ & C & 26.5 & 11.0 & 0.38 & $14 \mathrm{mos}$ & C & 26.5 & 15.2 & 0.16 \\
\hline $44 \mathrm{mos}$ & D & 27.0 & 10.5 & 0.68 & $44 \operatorname{mos}$ & D & 26.5 & 14.0 & 0.27 \\
\hline
\end{tabular}

*These modules have at least one impact-cracked cell.

Note: $A=$ Receiving inspection $\quad C=$ Second Field Return

$B=$ First Field Return $\quad D=$ Third Field Return 


\subsection{Block II-Model D Modules}

\subsubsection{Visual}

Typical conditions noted on the first examination of these modules are staining of the main collectors, broken surface bubbles, slight edge-seal delamination, splits in the RTV, and delamination on the cell.

During the second analysis of these modules, in addition to the changes noted above, impact-cracked cells were found. As this analysis was made after a hailstorm that struck the array in May 1978, the cells were assumed to have been cracked by hail impact.

The following summarizes new or worsenting problems found during the third visual inspection (after an additional 30 months of exposure).

Ruet colored main collectors were found on 494 cells during the third inspection compared to 428 cells in the second inspection.

An area of delamination, 1/32-inch wide, was found on one cell. In addition, delamination measuring 5/32-inch long and 1/32-inch wide was found on a cell in the area in front of a rear-side interconnect on one module.

Two modules each contained one impact-cracked cell during the second analysis. During the third analysis, an additional seven impact-cracked cells were found on fuur of the modules. The cause of the increase was assumed to be a second hailstorm which struck the array in June 1981 .

Shore hardness changes were pinimal. During the second analys is the encapsulant of ten modules with 18 months exposure were found to have a Shore hardness ranging from 24 to 59 points. After an additional 26 months exposure, the measurements ranged from 26 to 60 points.

The RTV of two modules after 16 months exposure was found to have a hardness ranging from 42 to 55 points. With an additional 26 months of field service, these values ranged from 43 to 56 points. 


\subsubsection{Electrical}

Twelve Model $\mathrm{D}$ modules were flashed before cleaning in the. LAPSS, and a normal shaped I-V curve was obtained for each module. The short-circuit currents ranged from 1.09 to 1.22 amp; and the open-circuit voltages ranged from 23.93 to $24.53 \mathrm{~V}$. The peak powers ranged from 17.58 to $19.76 \mathrm{~W}$.

After cleaning, the modules were retested in the LAPSS. Increases in the peak powers ranged from $13.59 \%$ to $20.13 \%$. The increases in the shortcircuit currents were also calculated and found to be close to the peak power increases. The results of the LAPSS tests and the percent of increase in the peak powers and the short-circuit currents can be found in Table 7 .

Forward and reverse dark curve measurements were made on each of the twelve modules. Typically, the voltage on the forward dark curve at 0.5 amp is on the order of $23.0 \mathrm{~V}$. When compared to the values found during the last test, eight were found to be unchanged, while four showed an increase of $0.5 \mathrm{~V}$.

During the reverse dark curve measurement, increases of 10 ma were found on two modules. Decreases of 50 and 5 ma were found on two other modules. The remaining eight modules were unchanged.

A high-voltage breakdown test was performed at $1000 \mathrm{~V}$ for one minute; no leakage current was found.

\subsection{Summary}

Most of the changes in the Model $C$ modules during the second and third analyses are cracked cells and discoloration of the AR coating, which has been discussed elsewhere in this report.

Impact-cracked cells account for the greatest potential electrical failure found on these modules. The radial cracks, emanating from the main impact area, continue to progress to the edges of the cells as the module is subjected to thermal cycling. The result is often a cell cut into multiple sections. These cells eventually become open-circuited when the module becomes hot, causing a failure. 
TABLE 7

MODEL D BLOCK II MODULES

COMPARATIVE TABLE OF LAPSS RESULTS

BEFORE AND AFTER CJEEANING

\begin{tabular}{|c|c|c|c|c|c|c|c|c|}
\hline \multirow[b]{2}{*}{$\operatorname{LL} S / N$} & \multicolumn{3}{|c|}{ Before Cleaning } & \multicolumn{3}{|c|}{ After Cleaning } & \multirow[b]{2}{*}{$\underset{\text { max }}{P_{\text {increase }}(\%)}$} & \multirow[b]{2}{*}{$\begin{array}{c}\mathrm{I}_{\mathrm{sc}} \\
\text { increase }(\%)\end{array}$} \\
\hline & $\begin{array}{c}I_{s c} \\
(\text { anps })\end{array}$ & $\begin{array}{c}v_{\text {oc }} \\
\text { (volts) }\end{array}$ & $\begin{array}{c}P_{\max } \\
\text { (watts) }\end{array}$ & $\begin{array}{c}\mathrm{I} s= \\
(\text { amps) }\end{array}$ & $\begin{array}{c}v_{o c} \\
(\text { volts) }\end{array}$ & $\begin{array}{c}P_{\max } \\
(\text { watts) }\end{array}$ & & \\
\hline 2332 & 1.20 & 24.53 & 19.04 & $1 .+2$ & 24.46 & 22.80 & 16.49 & 15.49 \\
\hline 2700 & 1.17 & 24.48 & 18.77 & 1.39 & 24.41 & 21.73 & 13.62 & 15.83 \\
\hline 1932 & 1.15 & 24.53 & 19.41 & 1.36 & 24.41 & 22.86 & 15.09 & 15.44 \\
\hline 4311 & 1.22 & 24.38 & 19.76 & 1.46 & 24.41 & 23.63 & 16.38 & 16.44 \\
\hline 4310 & 1.18 & 24.32 & 18.33 & 1.45 & 24.46 & 22.95 & 20.13 & 18.62 \\
\hline 2341 & 1.11 & 24.23 & 18.24 & 1.34 & 24.26 & 22.17 & 17.73 & 17.16 \\
\hline 4213 & 1.15 & 24.48 & 19.52 & 1.35 & 24.61 & 22.59 & 13.59 & 14.81 \\
\hline 4338 & 1.13 & 24.23 & 17.76 & 1.32 & 24.31 & 20.8 & 15.35 & 14.39 \\
\hline 4348 & 1.09 & 24.13 & 17.97 & 1.30 & 24.31 & 21.52 & 18.02 & 16.15 \\
\hline 4138 & 1.13 & 23.93 & 17.58 & 1.34 & 23.97 & 21.10 & 16.68 & 15.67 \\
\hline 4317 & 1.09 & 24.19 & 18.11 & 1.32 & 24.19 & 21.53 & $1 ? .42$ & 17.42 \\
\hline 4319 & 1.12 & 24.07 & 18.21 & 1.33 & 24.06 & 21.86 & 16.70 & 15.79 \\
\hline
\end{tabular}


Numerous Model C and Model D modules have one or more cracked cells, which will eventually fail. This type of failure rose sharply after the hailstorm of May 1978; the number of impact-cracked cells found during the third analysis after a second hailstorm in June 1981 has tripled. These numbers indicate a potentially drastic increase in the failure rate in the near future. Aside from the problems mentioned above, the Model $D$ modules show little or no change.

Further details of physical and electrical degradation incurred by modules at MIT LL test sites can be found in References 1-15.

Acknowledgement - The author is grateful to David Klein for his assistance in the preparation of this report and to Sharon Howland, Robin Torcoletti, and I,inda Cowan for their assistance in the typing of previous reports. 
THIS PAGE

\section{WAS INTENTIONALLY \\ LEFT BLANK}




\section{REFERENCES}

1. S.E. Forman, "Summary of Field Experience of Photovoltaic Modules at Various MIT LL Test Sites," C00-4094-8, Lincoln Laboratory, M.I.T. (22 March 1978).

2. S.E. Forman, "Endurance and Soil Accumulation Testing of Photovoltaic Modules at Various MIT LL Test Sites," C00-4094-23, Lincoln Laboratory, M.I.T. (28 September 1978).

3. S.E. Forman and M.P. Themelis, "Quarterly Report for 10/1/78 to $12 / 31 / 78$ on Photovoltaic Module Performance at Mead, Nebraska, Test Site," COO-4094-40, Lincoln Laboratory, M.I.T. (1 April 1979).

4. S.E. Forman and M.P. Themelis, "Quarterly Report for Solar Photovoltaic Project, Materials, Processes and Testing Activities for Period 1 January to 31 March 1979," C00-4094-55, Lincoln Laboratory, M.I.T. (30 June 1979).

5. S.E. Forman and M.P. Themelis, "Quarterly Report, Solar Photovoltaic Project, Materials, Processes and Testing Activities for the Period 1 April 1979 to 30 June 1979," C00-4094-60, Lincoln Laboratory, M.I.T. (31 October 1979).

6. S.E. Forman and M.P. Themelis, "Technical Progress Report, Materials, Processes and Testing Laboratory for the Period July, August, September, October 1979," Co0-4094-83, Lincoln Laboraţory, M.I.T. (15 March 1980).

7. S.E. Forman, "Visual Defects in Terrestrial Photovoltaic Modules," Co0-4094-6, Lincoln Laboratory, M.I.T. (21 March 1978).

8. S.E. Forman and M.P. Themelis, "Technical Progress Report, Materials, Processes and Testing Laboratory for the Period November, December 1979, January, February 1980," DOE/ET/20279-113, Lincoln Laboratory, M.I.T. (30 November. 1980).

9. S.E. Forman and M.P. Themelis, "Materials, Processes and Testing Laboratory, Technical Progress Report: March, April, May, June 1980," Technical Report, January 1981. (DOE/ET/20279-114)

10. S.E. Forman and M.P. Themelis, "Materials, Process and Testing Laboratory, Technical Progress Report: July, August, September, October 1980," Technical Report,-January 1981. (DOE/ET/20279-117) 
11. S.E. Forman and M.P. Themelis, "Reliability of Terrestrial Photovoltaic Modules at Various DOE/MIT Lincoln Laboratory Test Sites," presented at the 15th IEEE Photovoltaic Specialists' Conference, Orlando, FL, 11-15 May 1981. (DOE/ET/20279-126)

12. S.E. Forman, "Performance of Terrestrial Photovoltaic Modules at MIT Lincoln Laboratory Experimental Photovoltaic Systems," Technical Report, 30 April 1981. (DOE/ET/20279-140)

13. S.E. Forman and M.P. Themelis, "Materials, Processes and Testing Technical. Progress Report,. November, December 1980, January, February 1981," 30 April 1981. (DOE/ET/20279-160)

14. S.E. Forman and M.P. Themelis, "Materials, Processes and Testing Technical Progress Report, March, April, May, June 1981. (in preparation).

15. S.E. Forman and M.P. Themelis, "Materials, Processes and Testing Technical Progress Report, July, Allgllst, September, October 1981." (DOE/ET/20279-173 in preparation). 